Supporting Information

\title{
Novel Methodology for the Preparation of Five-, Seven-, and Nine- Membered Fused Rings on $\mathrm{C}_{60}$
}

\author{
Maria Hatzimarinaki, and Michael Orfanopoulos* \\ Department of Chemistry, University of Crete, 71409 Iraklion, Crete, Greece
}

\begin{tabular}{cc} 
Pages S2 to S6 & Experimental Procedures \\
\hline Page S7 & ${ }^{1}$ H NMR spectrum for $\boldsymbol{E}, \mathbf{Z}-\mathbf{1}$ isomeric mixture \\
\hline Pages S8 to S12 & 1D and 2D NMR spectra for $\boldsymbol{E}$-syn-2 \\
\hline Page S13 & FAB-MS spectrum for $\boldsymbol{E}$-syn-2 \\
\hline Pages S14 to S17 & 1D and 2D NMR spectra for $\mathbf{3}$ and $\boldsymbol{E}-\boldsymbol{Z}$-4 \\
\hline Pages S18 to S19 & 1D NMR and GC-MS spectra for isomeric \\
mixture of $\mathbf{7}$
\end{tabular}




\section{Experimental Procudures}

General Considerations. ${ }^{1} \mathrm{H}$ NMR and ${ }^{13} \mathrm{C}$ NMR spectra were recorded on a $500 \mathrm{MHz}$ spectrometer. Chemical shifts are reported in ppm downfield from $\mathrm{Me}_{4} \mathrm{Si}$, by using the residual solvent peak as internal standard. HPLC analyses have been carried out on $\mathrm{C}_{18}$ reverse phase columns with detection at $326 \mathrm{~nm}$. A mixture of toluene/acetonitrile (55/45) was used as eluent at 1 $\mathrm{ml} / \mathrm{min}$ flow rates. TLC was carried out on $\mathrm{SiO}_{2}$ (silica gel $\mathrm{F}_{254}$ ). Photochemical reactions were carried out by a $300-\mathrm{W}$ xenon lamp as the light source, using a pyrex filter.

\section{Synthesis of $E, Z-1$ mixture}

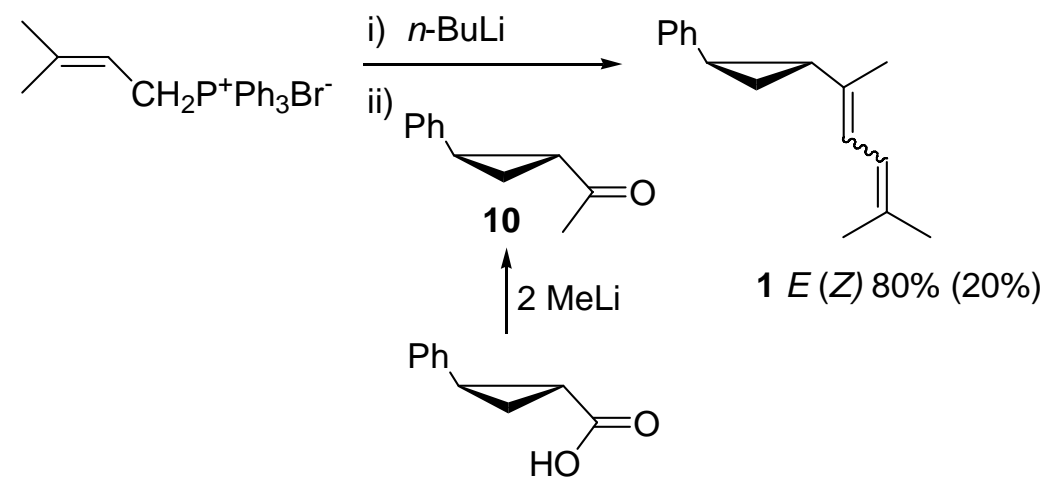

(trans-2-Phenylcyclopropyl)ethanone (10). ${ }^{\mathbf{i}}$ To a cooled solution $\left(-78{ }^{\circ} \mathrm{C}\right)$ of the commercially available trans-2-phenyl-1-cyclopropanecarboxylic acid $(1.52 \mathrm{~g}, 9.38 \mathrm{mmol})$ in anhydrous ether, under a nitrogen atmosphere was added slowly MeLi (13.3 mL, 1.5 M in ether, $20.0 \mathrm{mmol})$. The reaction mixture was stirred at $-78{ }^{\circ} \mathrm{C}$ for $15 \mathrm{~min}$ and then was warmed to $0{ }^{\circ} \mathrm{C}$, stirred for $1 \mathrm{~h}$, and carefully treated with water. The ether phase was separated, dried $\left(\mathrm{MgSO}_{4}\right)$ and evaporated to provide the ketone as an oil (1.2 g, $7.5 \mathrm{mmol}, 80 \%) .{ }^{1} \mathrm{H} \mathrm{NMR}\left(500 \mathrm{MHz}, \mathrm{CDCl}_{3}\right): \delta 1.41\left(\mathrm{dt}, J_{1}=\right.$ $\left.7.63 \mathrm{~Hz}, J_{2}=4.37 \mathrm{~Hz}, 1 \mathrm{H}\right), 1.70\left(\mathrm{dt}, J_{1}=9.0 \mathrm{~Hz}, J_{2}=4.37 \mathrm{~Hz}, 1 \mathrm{H}\right), 2.25\left(\mathrm{dt}, J_{1}=9.0 \mathrm{~Hz}, J_{2}=4.37\right.$ $\mathrm{Hz}, 1 \mathrm{H}), 2.33(\mathrm{~s}, 3 \mathrm{H}), 2.55\left(\mathrm{dt}, J_{1}=7.63 \mathrm{~Hz}, J_{2}=4.37 \mathrm{~Hz}, 1 \mathrm{H}\right), 7.12(\mathrm{~d}, J=7.43 \mathrm{~Hz}, 2 \mathrm{H}), 7.24(\mathrm{t}, J$ $=7.43 \mathrm{~Hz}, 1 \mathrm{H}), 7.31(\mathrm{~d}, J=7.43 \mathrm{~Hz}, 2 \mathrm{H}) ;{ }^{13} \mathrm{C} \mathrm{NMR}\left(125 \mathrm{MHz}, \mathrm{CDCl}_{3}\right): \delta 18.96,28.85,30.66$, $32.72,125.89,126.38,128.36,140.17,206.61$.

2-(2-phenylcyclopropyl)-5-methyl-2,4-hexadiene (E,Z-1). To a cooled mixture $\left(0{ }^{\circ} \mathrm{C}\right)$ of triphenylphosphoranylidene-3-methyl-2-butene in dry THF was added a $6.1 \mathrm{~mL}$ solution of $n$-BuLi (1.4 $\mathrm{M}$ in hexane) under $\mathrm{N}_{2}$ atmosphere. The solution turned red due to the formation of the 
corresponding ylide. After the mixture was stirred for $1 \mathrm{~h}$ at room temperature, a solution of the above ketone (1.2 g, $7.5 \mathrm{mmol})$ in $10 \mathrm{~mL}$ of dry THF was added dropwise. The resulting mixture was stirred at room temperature for $20 \mathrm{~h}$ and poured into $100 \mathrm{~mL}$ of hexane. Triphenylphosphine oxide $\left(\mathrm{Ph}_{3} \mathrm{PO}\right)$ precipitated. After filtration, the solution was concentrated, and the residue was chromatographed $\left(\mathrm{SiO}_{2}\right.$, hexane) to give $1.1 \mathrm{~g}$ of the diene $\boldsymbol{E}, \boldsymbol{Z}-\mathbf{1}(5.21 \mathrm{mmol}, 70 \%) .{ }^{1} \mathrm{H} \mathrm{NMR}$ of $\boldsymbol{E}$ $1\left(500 \mathrm{MHz}, \mathrm{CDCl}_{3}\right): \delta 1.02\left(\mathrm{dt}, J_{1}=8.55 \mathrm{~Hz}, J_{2}=5.43 \mathrm{~Hz}, 1 \mathrm{H}\right), 1.19\left(\mathrm{dt}, J_{1}=8.55 \mathrm{~Hz}, J_{2}=5.43\right.$ $\mathrm{Hz}, 1 \mathrm{H}), 1.62(\mathrm{~s}, 3 \mathrm{H}), 1.65(1 \mathrm{H}$, hidden under the signals of methyl groups), $1.67(\mathrm{~s}, 3 \mathrm{H}), 1.72(\mathrm{~s}$, $3 \mathrm{H}), 1.89\left(\mathrm{dt}, J_{1}=8.52 \mathrm{~Hz}, J_{2}=5.25 \mathrm{~Hz}, 1 \mathrm{H}\right), 5.94(\mathrm{~d}, J=11.25 \mathrm{~Hz}, 1 \mathrm{H}), 6.01(\mathrm{~d}, J=11.25 \mathrm{~Hz}$, 1H), $7.00(\mathrm{~d}, J=7.45 \mathrm{~Hz}, 2 \mathrm{H}), 7.06(\mathrm{t}, J=7.45 \mathrm{~Hz}, 1 \mathrm{H}), 7.17$ (t, $J=7.45 \mathrm{~Hz}, 2 \mathrm{H}) ;{ }^{13} \mathrm{C}-\mathrm{NMR}(125$ $\left.\mathrm{MHz}, \mathrm{CDCl}_{3}\right): \delta 14.4,14.6,18.1,23.7,26.3,32.4,120.3,121.1,125.4,125.7,128.3,133.0,134.7$, 143.0. ${ }^{1} \mathrm{H}-\mathrm{NMR}$ of $\boldsymbol{Z}-\mathbf{1}\left(500 \mathrm{MHz}, \mathrm{CDCl}_{3}\right): \delta 1.08\left(\mathrm{dt}, J_{1}=8.55 \mathrm{~Hz}, J_{2}=5.43 \mathrm{~Hz}, 1 \mathrm{H}\right), 1.16\left(\mathrm{dt}, J_{1}=\right.$ $\left.8.55 \mathrm{~Hz}, J_{2}=5.43 \mathrm{~Hz}, 1 \mathrm{H}\right), 1.57(\mathrm{~s}, 3 \mathrm{H}), 1.65(\mathrm{~s}, 3 \mathrm{H}), 1.68(\mathrm{~s}, 3 \mathrm{H}), 1.98\left(\mathrm{dt}, J_{1}=8.52 \mathrm{~Hz}, J_{2}=5.25\right.$ $\mathrm{Hz}, 1 \mathrm{H}), 2.00\left(\mathrm{dt}, J_{1}=8.52 \mathrm{~Hz}, J_{2}=5.25 \mathrm{~Hz}, 1 \mathrm{H}\right), 6.03(\mathrm{~d}, J=11.42 \mathrm{~Hz}, 1 \mathrm{H}), 6.08(\mathrm{~d}, J=11.42 \mathrm{~Hz}$, 1H), $7.01(\mathrm{~d}, J=7.45 \mathrm{~Hz}, 2 \mathrm{H}), 7.16(\mathrm{t}, J=7.45 \mathrm{~Hz}, 1 \mathrm{H}), 7.17$ (t, $J=7.45 \mathrm{~Hz}, 1 \mathrm{H}) ;{ }^{13} \mathrm{C}-\mathrm{NMR}(125$ $\left.\mathrm{MHz}, \mathrm{CDCl}_{3}\right): \delta 14.7,18.0,20.2,22.8,25.9,32.4,120.8,123.1,125.5,125.8,128.3,133.6,134.7$, 142.9. The precursor to the ylide, the phosphonium salt, was prepared in $90 \%$ yield by heating 4 bromo-2-methyl-2-butene (Aldrich) and equimolar amount of triphenylphosphine in sealed tube for $12 \mathrm{~h}$ at $100{ }^{\circ} \mathrm{C}$. The phosphonium salt was collected as a white solid and washed with hot toluene. ${ }^{1} \mathrm{H}$ $\operatorname{NMR}\left(500 \mathrm{MHz}, \mathrm{CDCl}_{3}\right): \delta 1.28(\mathrm{~d}, J=3.9 \mathrm{~Hz}, 3 \mathrm{H}), 1.67(\mathrm{~d}, J=5.8 \mathrm{~Hz}, 3 \mathrm{H}), 4.52\left(\mathrm{dd}, J_{H-P}=14.4\right.$ $\left.\mathrm{Hz}, J_{H-H}=7.7 \mathrm{~Hz}, 2 \mathrm{H}\right), 5.13(\mathrm{~m}, 1 \mathrm{H}), 7.63-7.90(\mathrm{~m}, 15 \mathrm{H})$.

Photochemical reaction of $\boldsymbol{E}, \boldsymbol{Z}-\mathbf{1}$ to $\mathbf{C}_{60}$. A solution of $\mathrm{C}_{60}(45.0 \mathrm{mg}, 0.063 \mathrm{mmol})$ and 30 -fold excess of diene $\boldsymbol{E}, \boldsymbol{Z}-\mathbf{1}(0.40 \mathrm{~g}, 1.89 \mathrm{mmol})$ in HPLC grade toluene $(100 \mathrm{~mL})$ was stirred and bubbled with argon for $30 \mathrm{~min}$ and subsequently irradiated for $30 \mathrm{~min}$. During irradiation, the reaction mixture was cooled with ice water and the reaction was monitored by HPLC. Toluene was removed under reduced pressure and the residue was washed and centrifuged five times with acetonitrile HPLC grade in order to remove the unreacted starting material $\boldsymbol{E}, \boldsymbol{Z}-\mathbf{1}$. Purification through by flash column chromatography $\left(\mathrm{SiO}_{2}\right.$, hexane:dichloromethane $\left.=4: 1\right)$ allowed the separation of unreacted $\mathrm{C}_{60}$ from the products as well as the isolation of the fullerene products in two fractions: the first one containing 3 and $\boldsymbol{E}, \boldsymbol{Z}-\mathbf{4}$ (the less polar compounds, 40\%) and the second one containing the major cycloadduct $\boldsymbol{E}$-syn-2 (the more polar compound, 60\%).

Mixture of 3 and $\boldsymbol{E}, \boldsymbol{Z}-4 .{ }^{1} \mathrm{H}$ NMR (500 MHz, $\mathrm{CDCl}_{3}$ ): $\delta 1.73$ (s, 3H of $\boldsymbol{E}-\mathbf{4}$ ), 1.78 (s, 3H of $\boldsymbol{E}-\mathbf{4}$ ), 1.84 (s, 3H of $\boldsymbol{E}-\mathbf{4}$ ), 1.91 (s, 3H of $\mathbf{3}$ or $\boldsymbol{Z}-\mathbf{4}$ ), 1.95 (s, 3H of $\mathbf{3}$ or $\boldsymbol{Z}-\mathbf{4}$ ), 2.00 (s, 3H of $\mathbf{3}$ or $\boldsymbol{Z}-\mathbf{4}$ ), 2.14 
(s, 3H of $\mathbf{3}$ or $\boldsymbol{Z}-\mathbf{4}$ ), 2,19 (s, 3H of $\mathbf{3}$ or $\boldsymbol{Z}-\mathbf{4}$ ), 2.20 (s, 3H of $\mathbf{3}$ or $\boldsymbol{Z}-\mathbf{4}$ ), 3.03 (m, 1H of $\boldsymbol{Z}-\mathbf{4}$ ), 3.14 (m, $1 \mathrm{H}$ of $\boldsymbol{E}-4), 2.30$ (broad d, $J=16.0 \mathrm{~Hz}, 1 \mathrm{H}$ of 3), 3.88 (dd, $J_{1}=13.18 \mathrm{~Hz}, J_{2}=8.52 \mathrm{~Hz}, 1 \mathrm{H}$ of $\boldsymbol{Z}-\mathbf{4}$ ), $3.96\left(\mathrm{dd}, J_{1}=12.98 \mathrm{~Hz}, J_{2}=8.16 \mathrm{~Hz}, 1 \mathrm{H}\right.$ of $\left.\boldsymbol{E}-4\right), 4.07(\operatorname{broad} \mathrm{t}, J=16.0 \mathrm{~Hz}, 1 \mathrm{H}$ of 3), $4.55(\mathrm{~d}, J=$ $9.86 \mathrm{~Hz}, 1 \mathrm{H}$ of $\boldsymbol{Z}-4), 4.70$ (d, $J=10.0 \mathrm{~Hz}, 1 \mathrm{H}$ of $\boldsymbol{E}-4), 4.95$ (d, $J=9.17 \mathrm{~Hz}, 1 \mathrm{H}$ of 3), 5.80 (t, $J=$ $8.52 \mathrm{~Hz}, 1 \mathrm{H}$ of $\boldsymbol{Z}-4), 5.83(\mathrm{t}, J=8.16 \mathrm{~Hz}, 1 \mathrm{H}$ of $\boldsymbol{E}-4), 6.09$ (s, $1 \mathrm{H}$ of 3), 6.17 (d, $J=16.0 \mathrm{~Hz}, 1 \mathrm{H}$ of 3), 6.42 (d, $J=16.4 \mathrm{~Hz}, 1 \mathrm{H}$ of $\boldsymbol{Z}-4), 6.43$ (d, $J=16.46 \mathrm{~Hz}, 1 \mathrm{H}$ of $\boldsymbol{E}-4), 6.57$ (d, $J=16.46 \mathrm{~Hz}, 1 \mathrm{H}$ of $\boldsymbol{E}-4), 6.64(\mathrm{~d}, J=16.4 \mathrm{~Hz}, 1 \mathrm{H}$ of $\boldsymbol{Z}-4), 6.85(\mathrm{~d}, J=9.17 \mathrm{~Hz}, 1 \mathrm{H}$ of 3$), 7.04-6.67$ (m, $5 \mathrm{H}$ of $3+5 \mathrm{H}$ of $\boldsymbol{Z}-\mathbf{4}+5 \mathrm{H}$ of $\boldsymbol{E}-4)$.

E-syn-2. ${ }^{1} \mathrm{H}$ NMR $\left(500 \mathrm{MHz}, \mathrm{CDCl}_{3}\right): \delta 1.85$ (s, 3H), 1.90 (s, 3H), 2.25 (s, 3H), 2.94 (dt, $J_{\text {gem }}=13$ $\left.\mathrm{Hz}, J_{\text {syn }}=4.38 \mathrm{~Hz}, 1 \mathrm{H}\right), 3.83\left(\mathrm{dt}, J_{\text {gem }}=13 \mathrm{~Hz}, J_{\text {anti }}=13 \mathrm{~Hz}, 1 \mathrm{H}\right), 4.70\left(\mathrm{dd}, J_{\text {anti }}=13 \mathrm{~Hz}, J_{\text {syn }}=4.38\right.$ $\mathrm{Hz}, 1 \mathrm{H}), 5.05\left(\mathrm{dd}, J_{\text {anti }}=13 \mathrm{~Hz}, J_{\text {syn }}=4.38 \mathrm{~Hz}, 1 \mathrm{H}\right), 6.15(\mathrm{~d}, J=10.92 \mathrm{~Hz}, 1 \mathrm{H}), 6.65(\mathrm{~d}, J=10.92$ $\mathrm{Hz}, 1 \mathrm{H}), 7.30$ (t, $J=7.56 \mathrm{~Hz}, 1 \mathrm{H}), 7.41$ (t, $J=7.56 \mathrm{~Hz}, 2 \mathrm{H}), 7.70(\mathrm{~d}, J=7.56 \mathrm{~Hz}, 2 \mathrm{H}) ;{ }^{13} \mathrm{C}-\mathrm{NMR}$ (125 MHz, $\left.\mathrm{CDCl}_{3}\right): \delta 16.77\left(\mathrm{Me}_{1}\right), 18.31\left(\mathrm{Me}_{2}\right), 26.37\left(\mathrm{Me}_{3}\right), 34.61\left(-\mathrm{CH}_{2}-\right), 59.90\left(C-\mathrm{H}_{1}\right), 63.95$ $\left(C-\mathrm{H}_{4}\right), 75.73\left(\mathrm{sp}^{3} \mathrm{C}_{60}\right), 76.00\left(\mathrm{sp}^{3} \mathrm{C}_{60}\right), 121.11(\mathrm{CH}=), 127.51(\mathrm{CH}=), 127.76(1 \mathrm{C},-\mathrm{Ph}), 128.48(2 \mathrm{C}$, -Ph), 128.84, 129.22 (2C, -Ph), 130.84 (1C, -Ph), 134.66, 135.54, 135.61, 135.93, 137.99, 139.16, $139.44,139.51,139.56,141.42,141.54,141.55,141.59$, 141.66, 141.73, 141.84, 141.88, 141.98, $142.01,142.08,142.09,142.33,142.38,142.44,142.45,142.82,142.90,142.99,144.19,144.23$, $144.31,144.38,144.89,144.92,145.00,145.04,145.06,145.08,145.13,145.44,145.54,145.72$, $145.75,145.85,145.92,145.97,146.05,146.19$, 146.83, 146.97, 147.02, 153.74, 154.54, 156.14, 156.17. FAB-MS: $\mathrm{m} / \mathrm{z}=933[\mathrm{M}]^{+}$. 
Synthesis of isomeric mixture E-cis-7, E-trans-7, Z-cis-7, Z-trans-7.

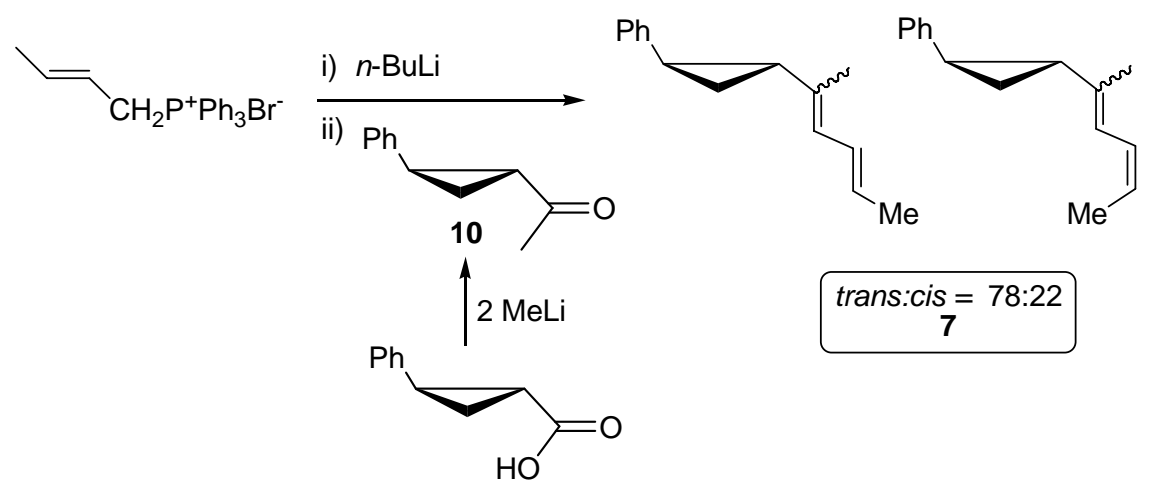

2-(2-phenylcyclopropyl)-2,4-hexadiene (E-cis-7, E-trans-7, Z-cis-7, Z-trans-7). This isomeric compound was prepared by Wittig coupling of triphenylphosphoranylidene-2-butene with $\mathbf{1 0}$ in dry THF, as described for diene $\boldsymbol{E}, \boldsymbol{Z}-\mathbf{1}(70 \%) .{ }^{1} \mathrm{H}$ NMR of $\boldsymbol{E}$-trans-7 (500 MHz, $\left.\mathrm{CDCl}_{3}\right): \delta 1.00\left(\mathrm{dt}, J_{1}=\right.$ $\left.8.55 \mathrm{~Hz}, J_{2}=5.43 \mathrm{~Hz}, 1 \mathrm{H}\right), 1.17\left(\mathrm{dt}, J_{1}=8.55 \mathrm{~Hz}, J_{2}=5.43 \mathrm{~Hz}, 1 \mathrm{H}\right), 1.58(1 \mathrm{H}$, hidden under the methyl signals), $1.67(\mathrm{~d}, J=6.72 \mathrm{~Hz}, 3 \mathrm{H}), 1.87\left(\mathrm{dt}, J_{1}=8.52 \mathrm{~Hz}, J_{2}=5.25 \mathrm{~Hz}, 1 \mathrm{H}\right), 5.52\left(\mathrm{dq}, J_{\text {trans }}=\right.$ $\left.14.92 \mathrm{~Hz}, J_{2}=6.72 \mathrm{~Hz}, 1 \mathrm{H}\right), 5.79(\mathrm{~d}, J=10.83 \mathrm{~Hz}, 1 \mathrm{H}), 6.19\left(\mathrm{dd}, J_{\text {trans }}=14.92 \mathrm{~Hz}, J_{2}=10.83 \mathrm{~Hz}\right.$, $1 \mathrm{H}), 7.00(\mathrm{~d}, J=7.45 \mathrm{~Hz}, 2 \mathrm{H}), 7.06(\mathrm{t}, J=7.45 \mathrm{~Hz}, 1 \mathrm{H}), 7.17(\mathrm{t}, J=7.45 \mathrm{~Hz}, 2 \mathrm{H}) ;{ }^{13} \mathrm{C}-\mathrm{NMR}$ of $\boldsymbol{E}$ trans-7 (125 MHz, $\left.\mathrm{CDCl}_{3}\right): \delta 14.6,14.7,18.2,23.6,31.7,118.9,123.6,125.7,126.6,127.7,128.2$, 134.9, 142.9; MS: $\mathrm{m} / \mathrm{z}=198\left(\mathrm{M}^{+}, 28\right)$. The precursor to the ylide, the phosphonium salt, was prepared in $90 \%$ yield by heating 4-bromo-2-butene and equimolar amount of triphenylphosphine in sealed tube for $12 \mathrm{~h}$ at $80{ }^{\circ} \mathrm{C}$. The phosphonium salt was collected as a white solid and washed with hot toluene. ${ }^{1} \mathrm{H}$ NMR $\left(500 \mathrm{MHz}, \mathrm{CDCl}_{3}\right): \delta 1.51(\mathrm{~d}, J=5.6 \mathrm{~Hz}, 3 \mathrm{H}), 4.60\left(\mathrm{dd}, J_{H-P}=14.16 \mathrm{~Hz}, J_{H-H}\right.$ $=6.67 \mathrm{~Hz}, 2 \mathrm{H}), 5.17(\mathrm{~m}, 1 \mathrm{H}), 5.87(\mathrm{~m}, 1 \mathrm{H}), 7.57-7.74(\mathrm{~m}, 15 \mathrm{H})$.

Photochemical reaction of E,cis-7, E,trans-7, Z,cis-7, Z,trans-7 mixture to $\mathrm{C}_{60}$. A solution of $\mathrm{C}_{60}$ $(45.0 \mathrm{mg}, 0.063 \mathrm{mmol})$ and 30 -fold excess of the isomeric mixture of diene $7(0.37 \mathrm{~g}, 1.86 \mathrm{mmol})$ in HPLC grade toluene $(100 \mathrm{~mL})$ was stirred and bubbled with argon for $30 \mathrm{~min}$ and subsequently irradiated for $30 \mathrm{~min}$. During irradiation, the reaction mixture was cooled with ice water and the reaction was monitored by HPLC. Toluene was removed under reduced pressure and the residue was washed and centrifuged five times with acetonitrile HPLC grade in order to remove the unreacted starting material 7. Separation of $\boldsymbol{E}-\mathbf{s y n - 8}$ and $\boldsymbol{E}, \boldsymbol{Z}-\mathbf{9}$ products was achieved using preparative HPLC column on $\mathrm{C}_{18}$ reverse phase. 
trans-E-syn-8 and $\boldsymbol{c i s - E - s y n - 8 . ~}{ }^{1} \mathrm{H}$ NMR $\left(500 \mathrm{MHz}, \mathrm{CDCl}_{3}\right): \delta 1.79$ (d, J=7.89 Hz, 3H of $\boldsymbol{c i s - \boldsymbol { E } -}$ $\boldsymbol{s y n - 8}), 1.81$ (d, $J=6.73 \mathrm{~Hz}, 3 \mathrm{H}$ of trans-E-syn-8), 2.20 (s, 3H of trans-E-syn-8), 2.21 (s, 3H of cis$\boldsymbol{E}$-syn-8), $2.87\left(\mathrm{dt}, J_{\mathrm{gem}}=13.0 \mathrm{~Hz}, J_{\mathrm{syn}}=4.53 \mathrm{~Hz}, 1 \mathrm{H}\right.$ of trans- $\boldsymbol{E}$-syn-8), $2.91\left(\mathrm{dt}, J_{\mathrm{gem}}=13.0 \mathrm{~Hz}, J_{\mathrm{syn}}\right.$ $=4.53 \mathrm{~Hz}, 1 \mathrm{H}$ of $\boldsymbol{c i s}-\boldsymbol{E}-\boldsymbol{s y n} \mathbf{n}-8), 3.80\left(\mathrm{q}, J_{\mathrm{gem}}=J_{\mathrm{anti}}=13.0 \mathrm{~Hz}, 1 \mathrm{H}\right.$ of trans- and $\boldsymbol{c i s}-\boldsymbol{E}$-syn-8), 4.62 $\left(\mathrm{dd}, J_{\text {anti }}=13.0 \mathrm{~Hz}, J_{\text {syn }}=4.53 \mathrm{~Hz}, 1 \mathrm{H}\right.$ of trans-E-syn-8$), 4.70\left(\mathrm{dd}, J_{\text {anti }}=13.0 \mathrm{~Hz}, J_{\text {syn }}=4.53 \mathrm{~Hz}, 1 \mathrm{H}\right.$ of $\boldsymbol{c i s}-\boldsymbol{E}$-syn-8), $5.02\left(\mathrm{dd}, J_{\mathrm{anti}}=13.0 \mathrm{~Hz}, J_{\mathrm{syn}}=4.38 \mathrm{~Hz}, 1 \mathrm{H}\right.$ of trans- and $\boldsymbol{c} \boldsymbol{i} \boldsymbol{s}-\boldsymbol{E}$-syn-8), 5.61 (dq, $J_{\mathrm{cis}}$ $=10.7 \mathrm{~Hz}, J_{2}=7.89 \mathrm{~Hz}, 1 \mathrm{H}$ of $\left.\boldsymbol{c i s}-\boldsymbol{E}-\boldsymbol{s y n}-\mathbf{8}\right), 5.80\left(\mathrm{dq}, J_{\text {trans }}=13.9 \mathrm{~Hz}, J_{2}=6.73 \mathrm{~Hz}, 1 \mathrm{H}\right.$ of $\boldsymbol{t r a n s}-\boldsymbol{E}-$ $\boldsymbol{s y n - 8}), 6.42(\mathrm{~m}, 2 \mathrm{H}$ of trans- and cis-E-syn-8), 6.47 (d, $J=10.9 \mathrm{~Hz}, 1 \mathrm{H}$ of trans-E-syn-8), 6.76 (d, $J$ $=11.1 \mathrm{~Hz}, 1 \mathrm{H}$ of $\boldsymbol{c i s}-\boldsymbol{E}-\boldsymbol{s y n}-8), 7.33(\mathrm{t}, J=7.31 \mathrm{~Hz}, 1 \mathrm{H}$ of trans- and $\boldsymbol{c i s}-\boldsymbol{E}-\boldsymbol{s y n}-8), 7.42(\mathrm{t}, J=7.31$ $\mathrm{Hz}, 2 \mathrm{H}$ of trans- and cis-E-syn-8), 7.70 (d, J=7.31 Hz, 2H of trans- and $\boldsymbol{c i s - E - s y n - 8 ) .}$

E,Z-9. ${ }^{1} \mathrm{H}$ NMR $\left(500 \mathrm{MHz}, \mathrm{CDCl}_{3}\right.$ ): $\delta 1.97$ (s, 3H of $\boldsymbol{Z}$-9), 1.99 (s, 3H of $\boldsymbol{E}$-9), 2.15 (d, $J=6.83 \mathrm{~Hz}$, 3H of $\boldsymbol{E}, \boldsymbol{Z}-\mathbf{9}$ ), 2.97 (m, 1H of $\boldsymbol{Z}-\mathbf{9}), 3.09$ (m, 1H of $\boldsymbol{E}-\mathbf{9}), 3.85$ (m, 1H of $\boldsymbol{E}, \boldsymbol{Z}-\mathbf{9}), 3.91$ (m, 1H of $\boldsymbol{Z}$-9), 3.99 (m, $1 \mathrm{H}$ of $\boldsymbol{E}-9), 4.61$ (d, $J=9.6 \mathrm{~Hz}, 1 \mathrm{H}$ of $\boldsymbol{Z}-9$ ), 4.77 (d, $J=9.6 \mathrm{~Hz}, 1 \mathrm{H}$ of $\boldsymbol{E}-9), 5.78$ (t, $J=$ $8.52 \mathrm{~Hz}, 1 \mathrm{H}$ of $\boldsymbol{Z}-\mathbf{9}), 5.83(\mathrm{t}, \mathrm{J}=8.16 \mathrm{~Hz}, 1 \mathrm{H}$ of $\boldsymbol{E}-\mathbf{9}), 6.20$ (dd, $J_{\text {trans }}=16.18 \mathrm{~Hz}, J_{2}=9.25 \mathrm{~Hz}, 1 \mathrm{H}$ of $\boldsymbol{E}-9), 6.31\left(\mathrm{dd}, J_{\text {trans }}=15.88 \mathrm{~Hz}, J_{2}=9.25 \mathrm{~Hz}, 1 \mathrm{H}\right.$ of $\left.\boldsymbol{Z}-9\right), 6.46\left(\mathrm{~d}, J_{\text {trans }}=16.16 \mathrm{~Hz}, 1 \mathrm{H}\right.$ of $\left.\boldsymbol{E}-\mathbf{9}\right), 6.59$ (d, $J_{\text {trans }}=15.88 \mathrm{~Hz}, 1 \mathrm{H}$ of $\left.\boldsymbol{Z}-\mathbf{9}\right), 7.31$ (t, $J=7.62 \mathrm{~Hz}, 1 \mathrm{H}$ of $\left.\boldsymbol{E}, \boldsymbol{Z}-\mathbf{9}\right), 7.39$ (t, $J=7.62 \mathrm{~Hz}, 2 \mathrm{H}$ of $\boldsymbol{E}, \boldsymbol{Z}$ 9), 7.59 (d, $J=7.62 \mathrm{~Hz}, 2 \mathrm{H}$ of $\boldsymbol{E}-\mathbf{9}), 7.66$ (d, $J=7.62 \mathrm{~Hz}, 2 \mathrm{H}$ of $\boldsymbol{Z}-\mathbf{9})$. 


\section{Spectral Data}

\section{A) Diene $(E, Z-1)$}

1) a) ${ }^{1} \mathrm{H}$ NMR (500 MHz, $\left.\mathrm{CDCl}_{3}\right)$

b) Expansion of the ${ }^{1} \mathrm{H}$ NMR spectrum in the region between 0.95 to $2.10 \mathrm{ppm}$.

a)

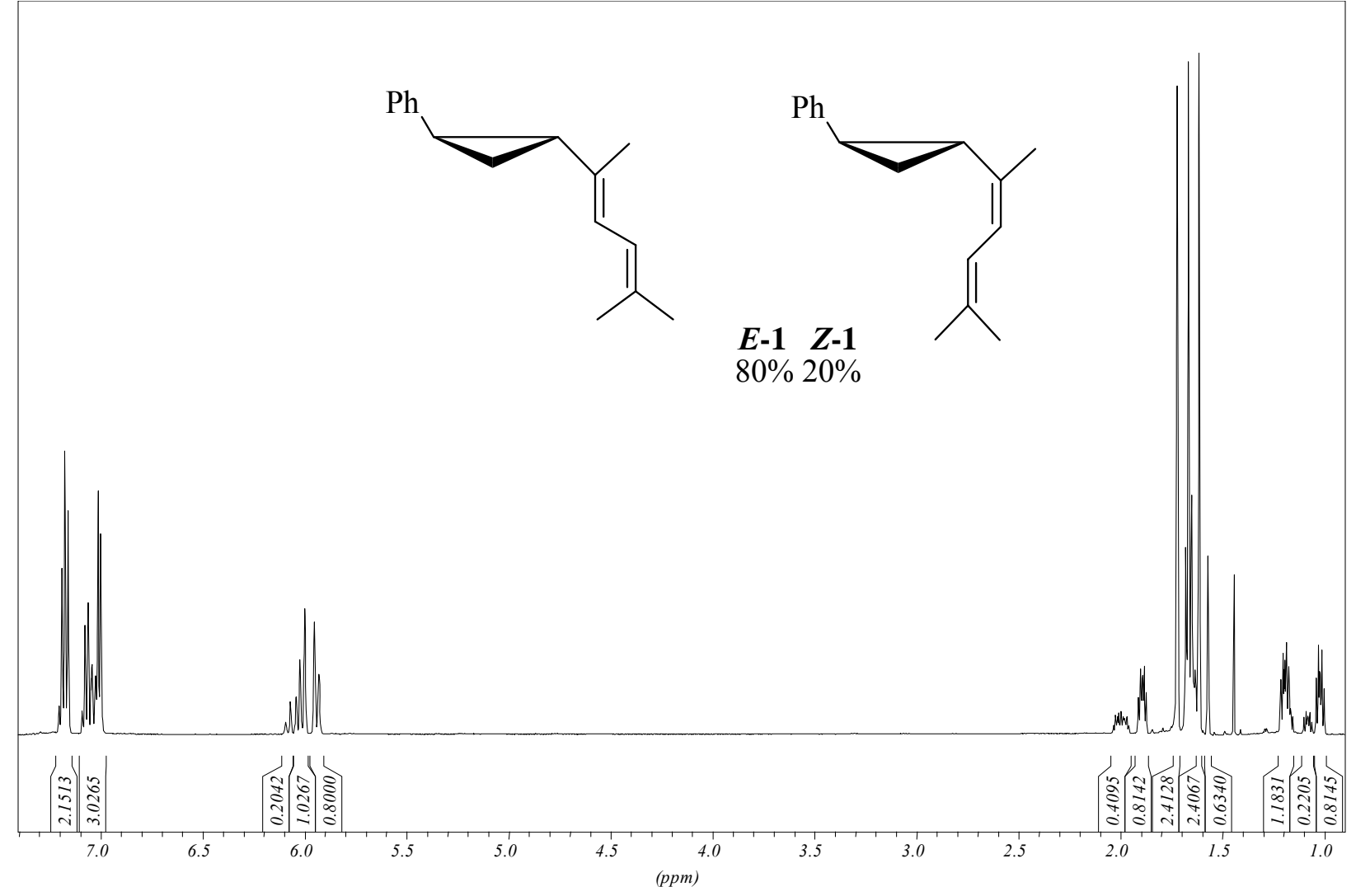

b)

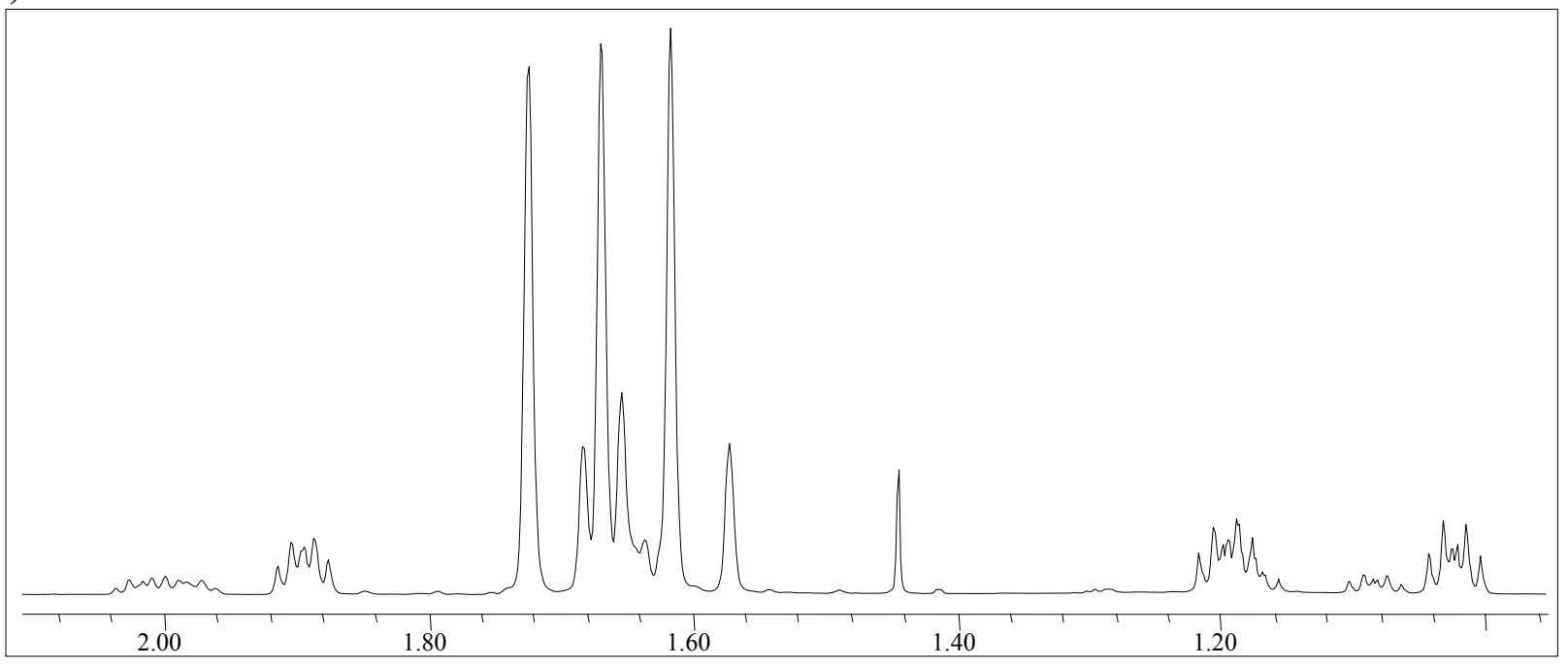


B) [60]Fullerene derivative $E$-syn-2

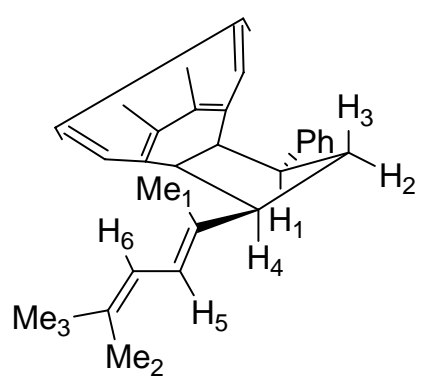

1) a) ${ }^{1} \mathrm{H} \mathrm{NMR}\left(500 \mathrm{MHz}, \mathrm{CDCl}_{3}\right)$ in the spectral region between 2.7 and $6.8 \mathrm{ppm}$.

b-f) ${ }^{1}$ H Homonuclear decoupling experiments. The protons, which are irradiated, are depicted in parenthesis.

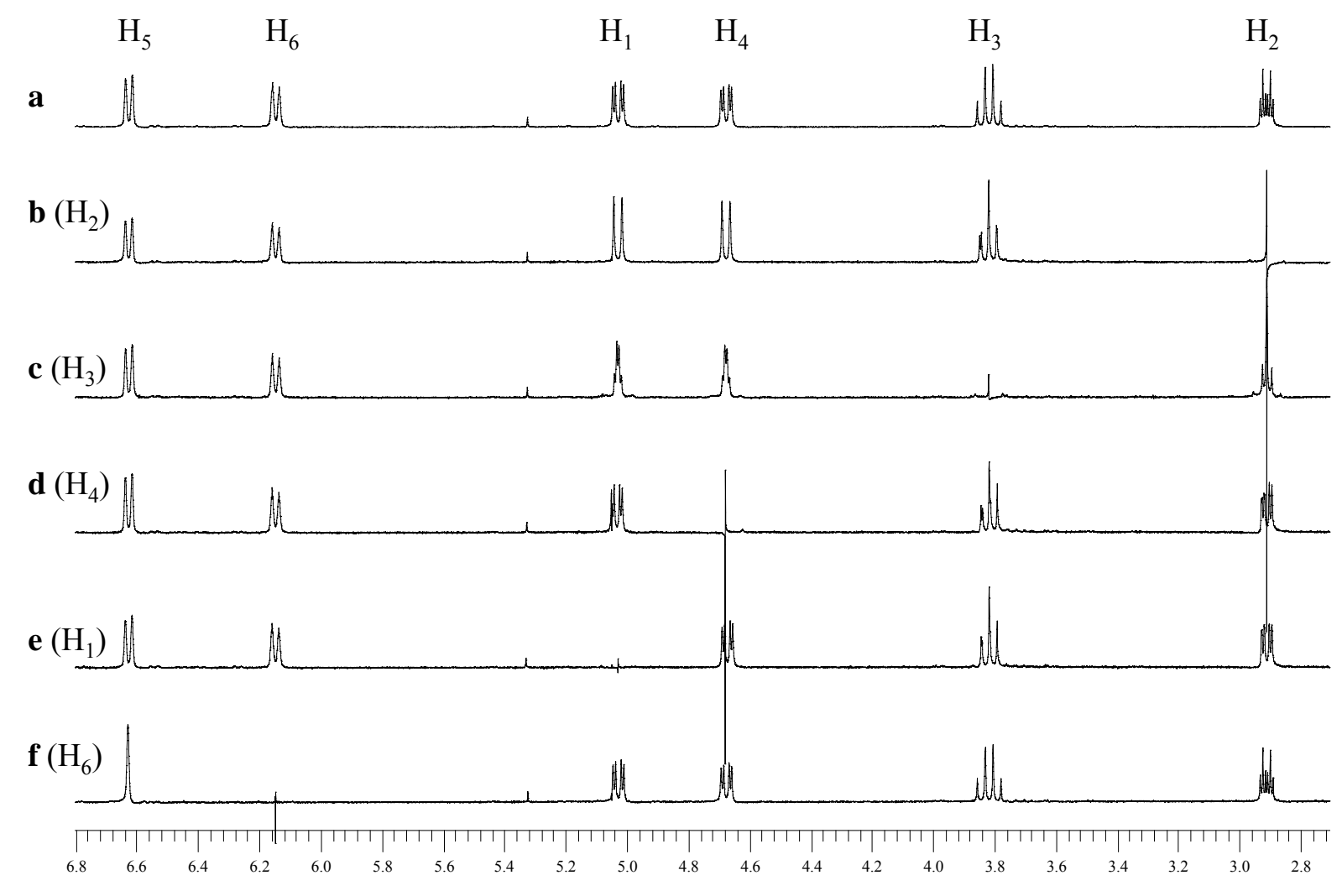


2) a) ${ }^{1} \mathrm{H}$ NMR (500 MHz, $\mathrm{CDCl}_{3}$ ) in the region of 1.6 to $8.0 \mathrm{ppm}$.

b-g) Difference Nuclear Overhauser Effect spectra of $E$-syn-2 with a lower right to upper left layout. The protons, which are irradiated, are depicted in parenthesis.
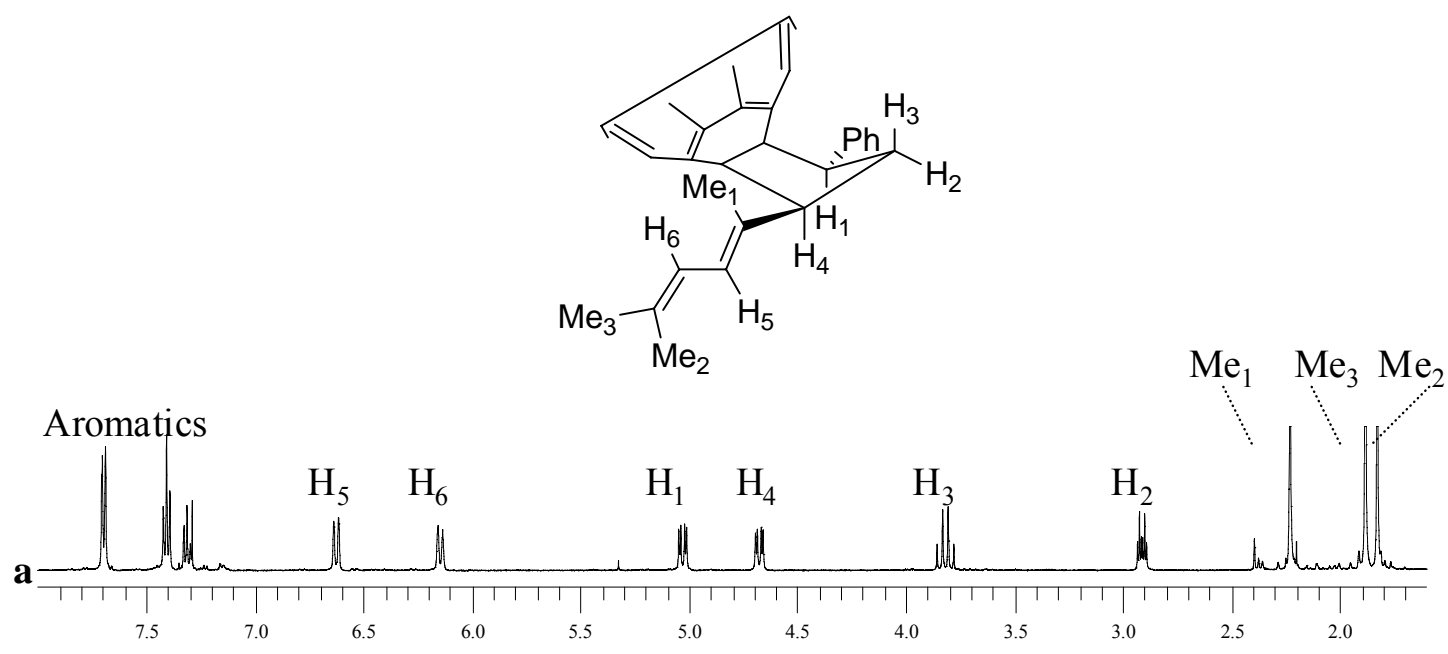

b $\left(\mathrm{Me}_{2}\right)$

c $\left(\mathrm{Me}_{1}\right)$

d $\left(\mathrm{H}_{2}\right)$

e $\left(\mathrm{H}_{3}\right)$

f $\left(\mathrm{H}_{4}\right)$

$\mathbf{g}\left(\mathrm{H}_{1}\right)$ 
3) a) ${ }^{13} \mathrm{C}$ NMR (500 MHz, $\left.\mathrm{CDCl}_{3}\right)$ in the region of 160.0 to $118.0 \mathrm{ppm}$.

b) Expansion of the ${ }^{13} \mathrm{C}$ NMR spectrum in the region between 159.4 to $151.0 \mathrm{ppm}$.

c) Expansion of the ${ }^{13} \mathrm{C}$ NMR spectrum in the region between 148.0 to $144.6 \mathrm{ppm}$.

d) Expansion of the ${ }^{13} \mathrm{C}$ NMR spectrum in the region between 144.6 to $140.0 \mathrm{ppm}$.

e) Expansion of the ${ }^{13} \mathrm{C}$ NMR spectrum in the region between 141.0 to $116.0 \mathrm{ppm}$.

a)
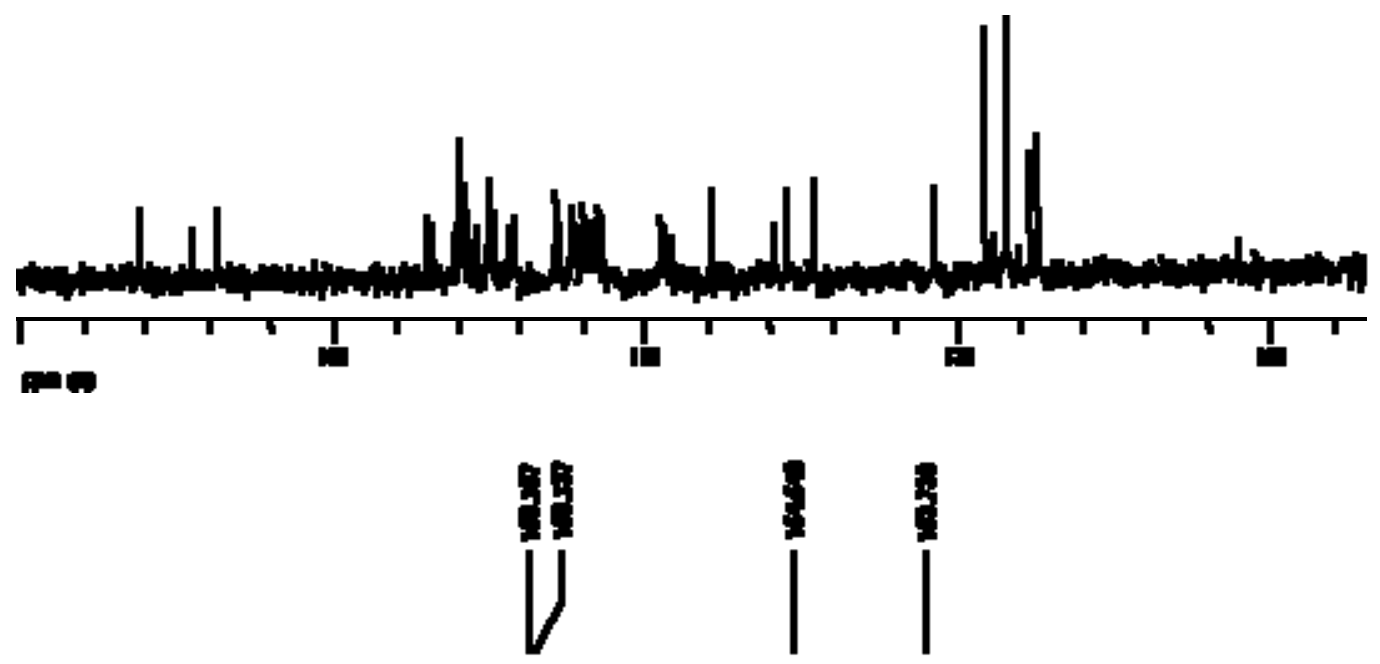

b)
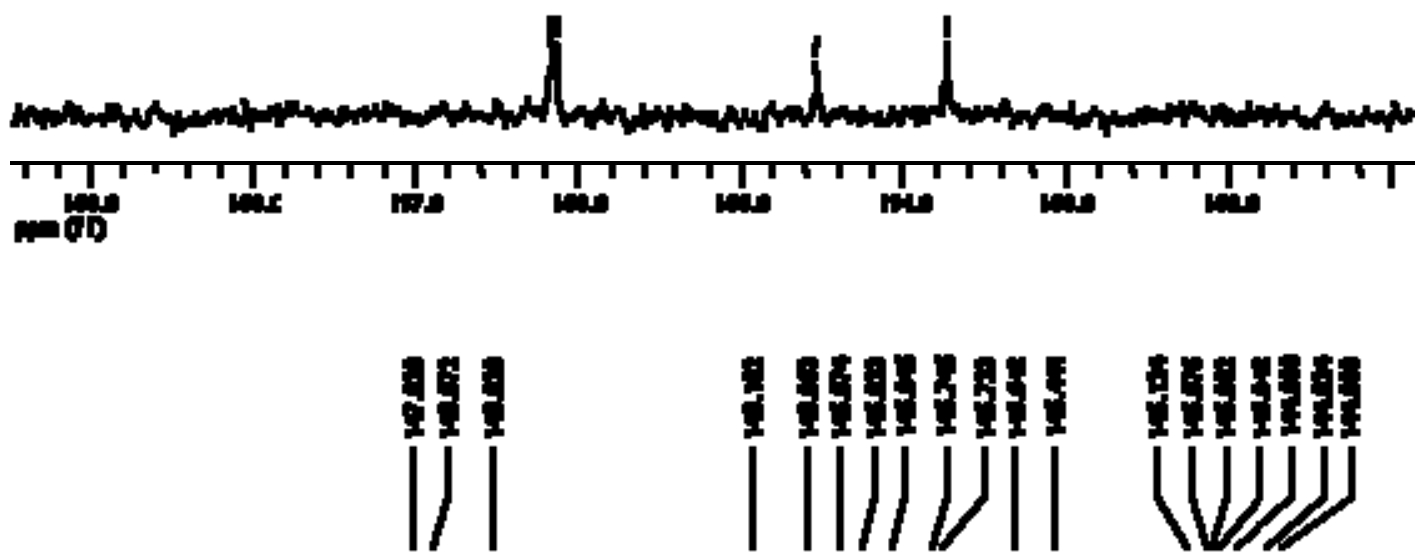

c)

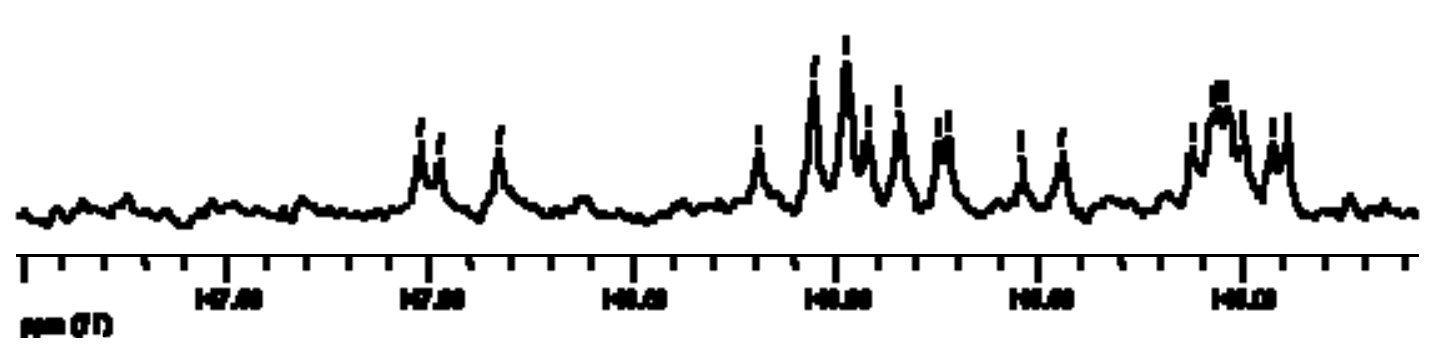



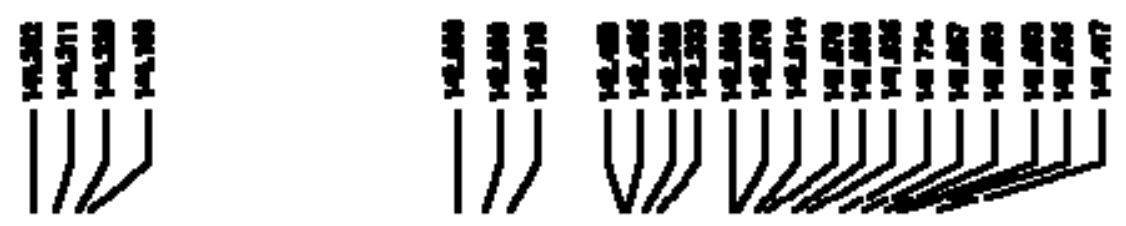

d)
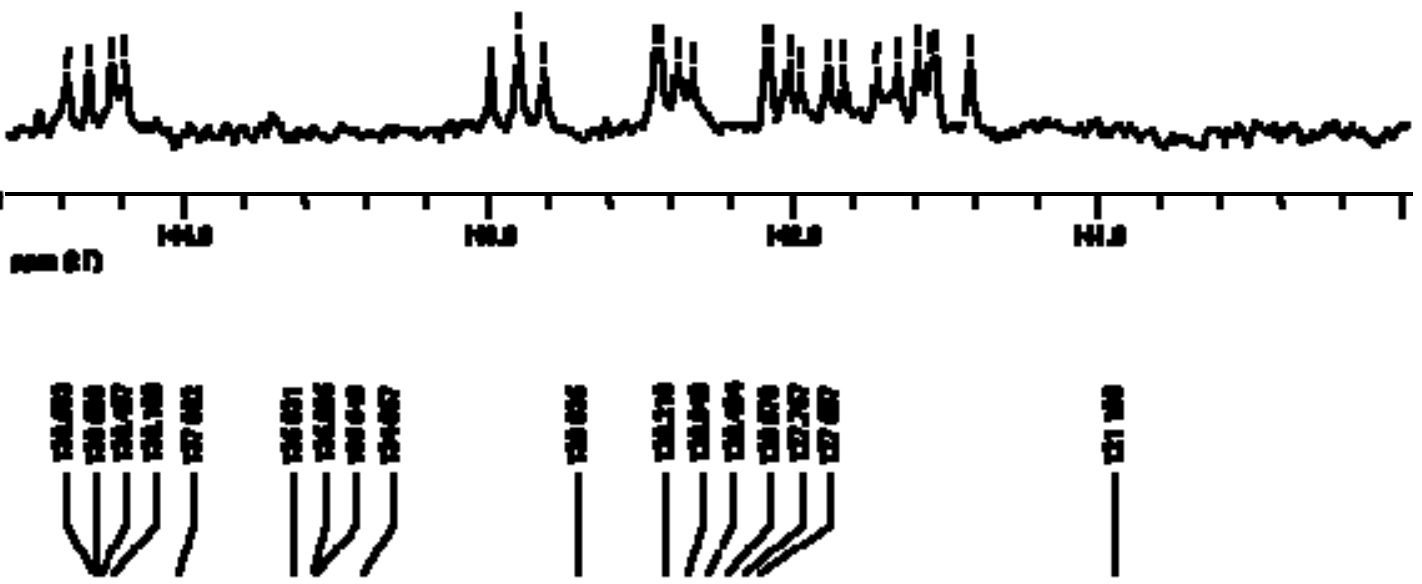

e)
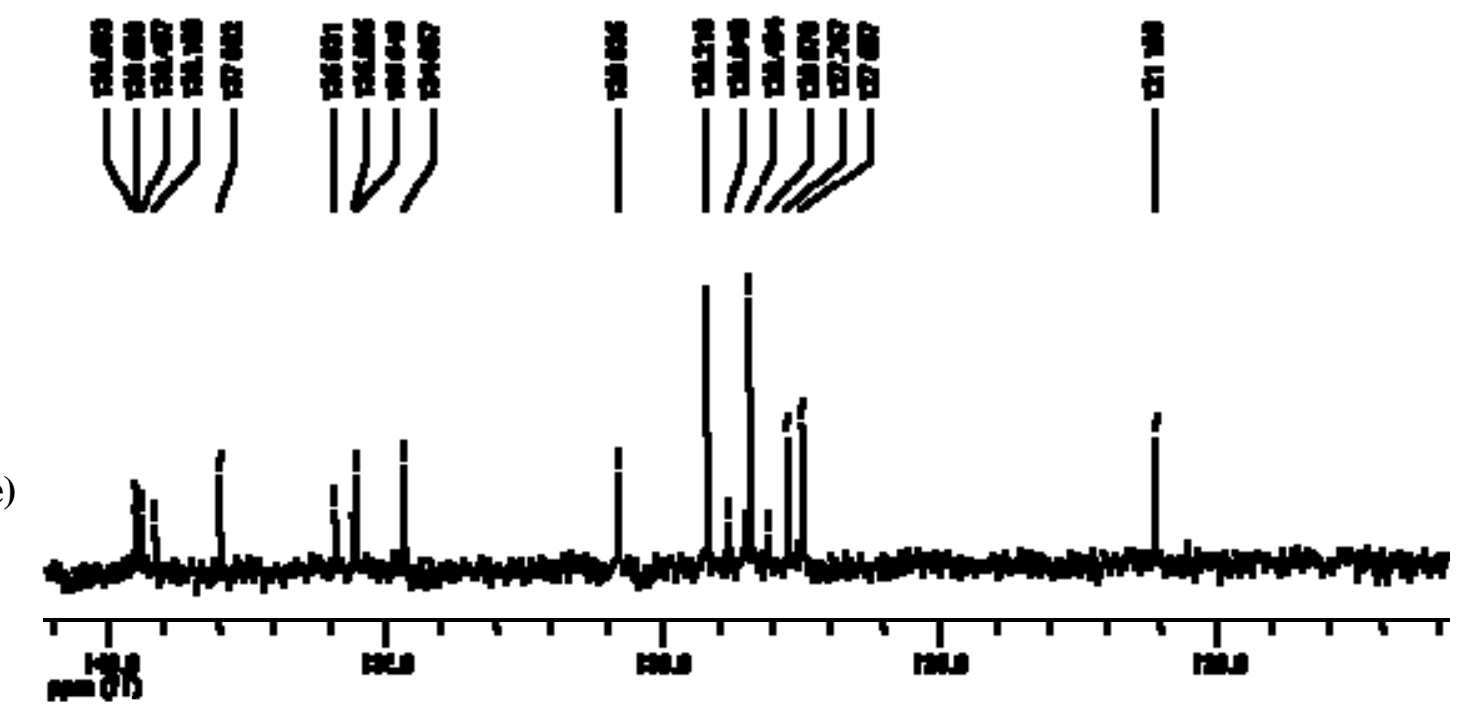
4) HMQC NMR spectrum

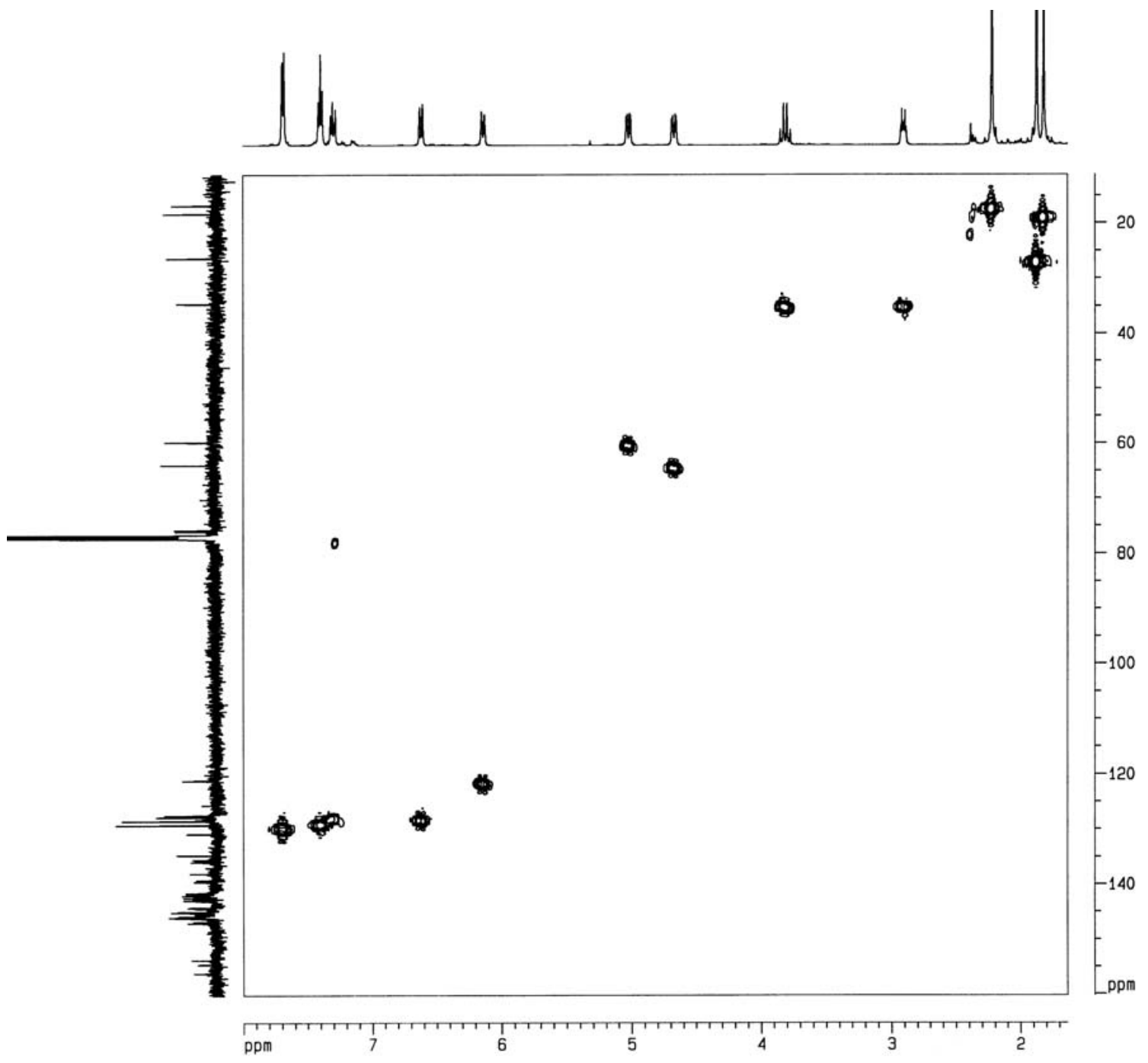

5) HMBC NMR spectrum

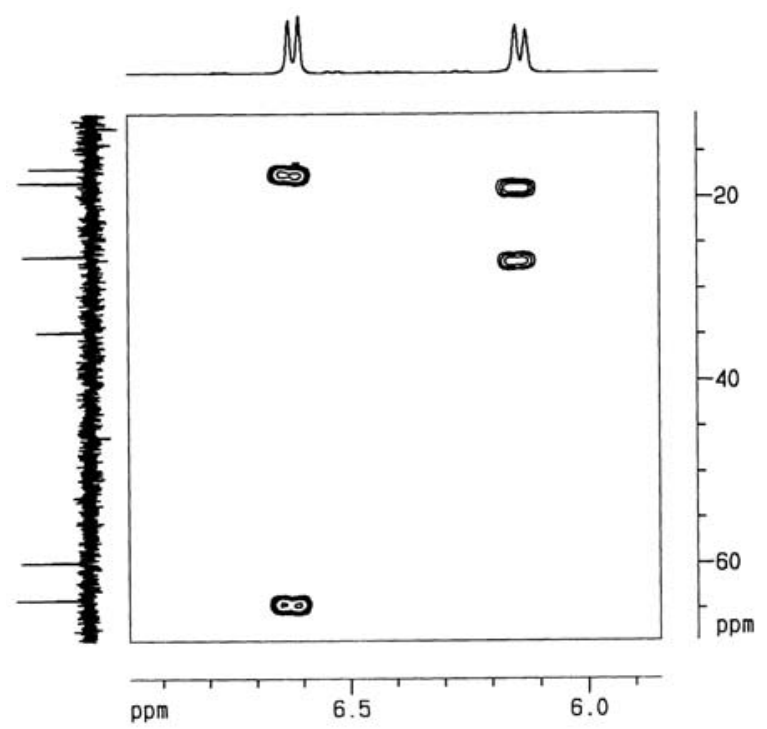


6) MS (FAB, NBA)

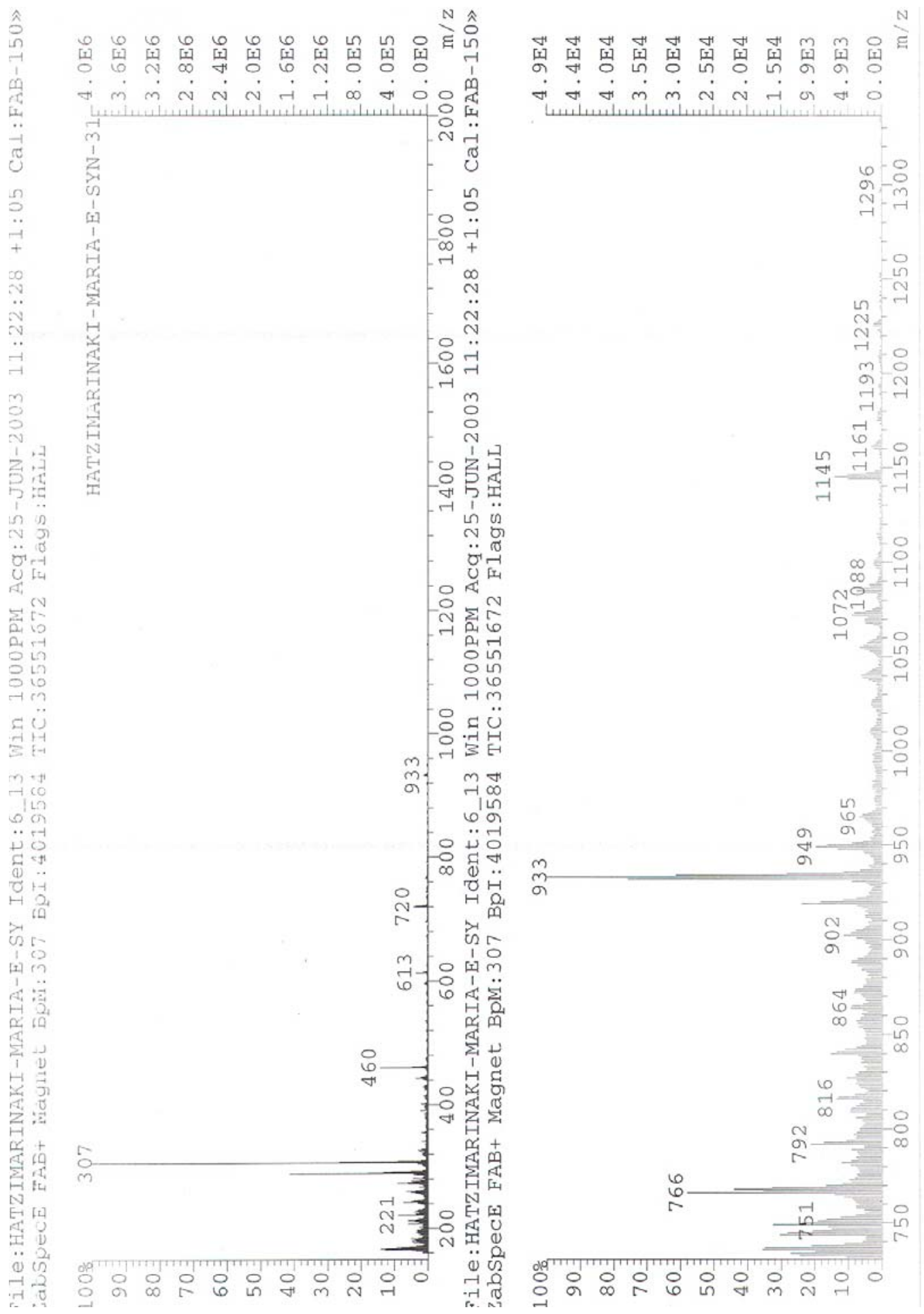


C) [60]Fullerene derivatives 3 and $E, Z-4$

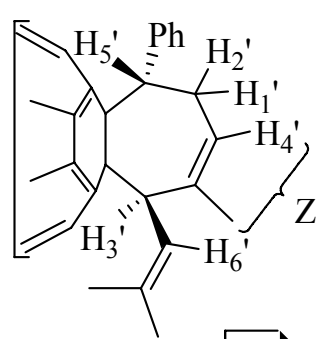

3

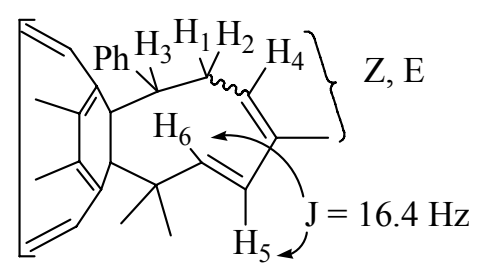

\section{E,Z-4}

1. a) ${ }^{1} \mathrm{H}$ NMR (500 $\mathrm{MHz}, \mathrm{CDCl}_{3}$ ) in the spectral region between 2.9 and $7.0 \mathrm{ppm}$.

b-h) ${ }^{1}$ H Homonuclear decoupling experiments. The protons, which are irradiated, are depicted in parenthesis.

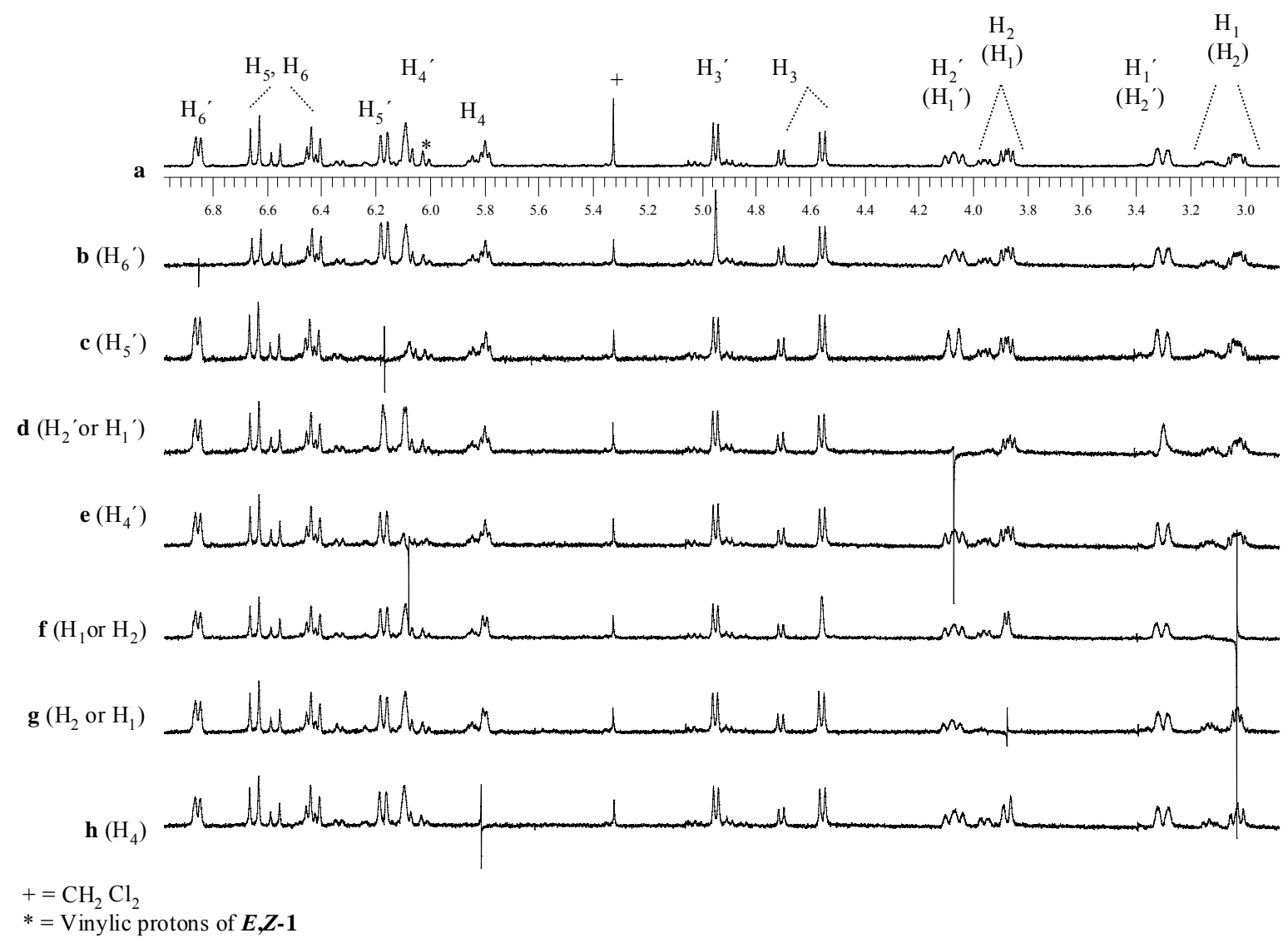


2) HMQC NMR spectrum (500 $\left.\mathrm{MHz}, \mathrm{CDCl}_{3}\right)$

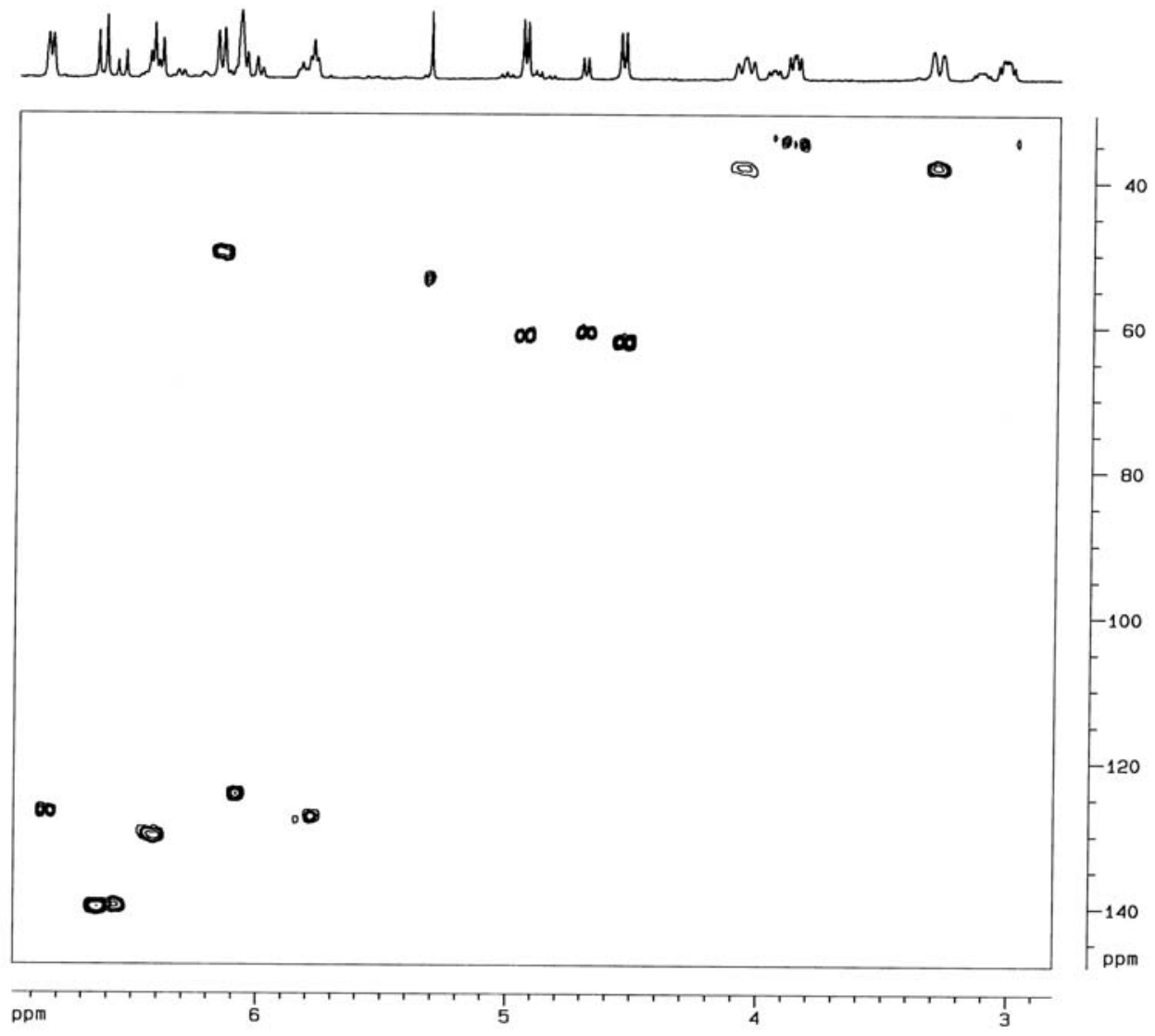

3) a) ${ }^{1} \mathrm{H}$ NMR (500 $\left.\mathrm{MHz}, \mathrm{CDCl}_{3}\right)$ in the region of 2.7 to $8.0 \mathrm{ppm}$.

b) Difference Nuclear Overhauser Effect spectrum which occurs when the ortho-phenyl protons of 3 and $E, Z-4$ are irradiated.
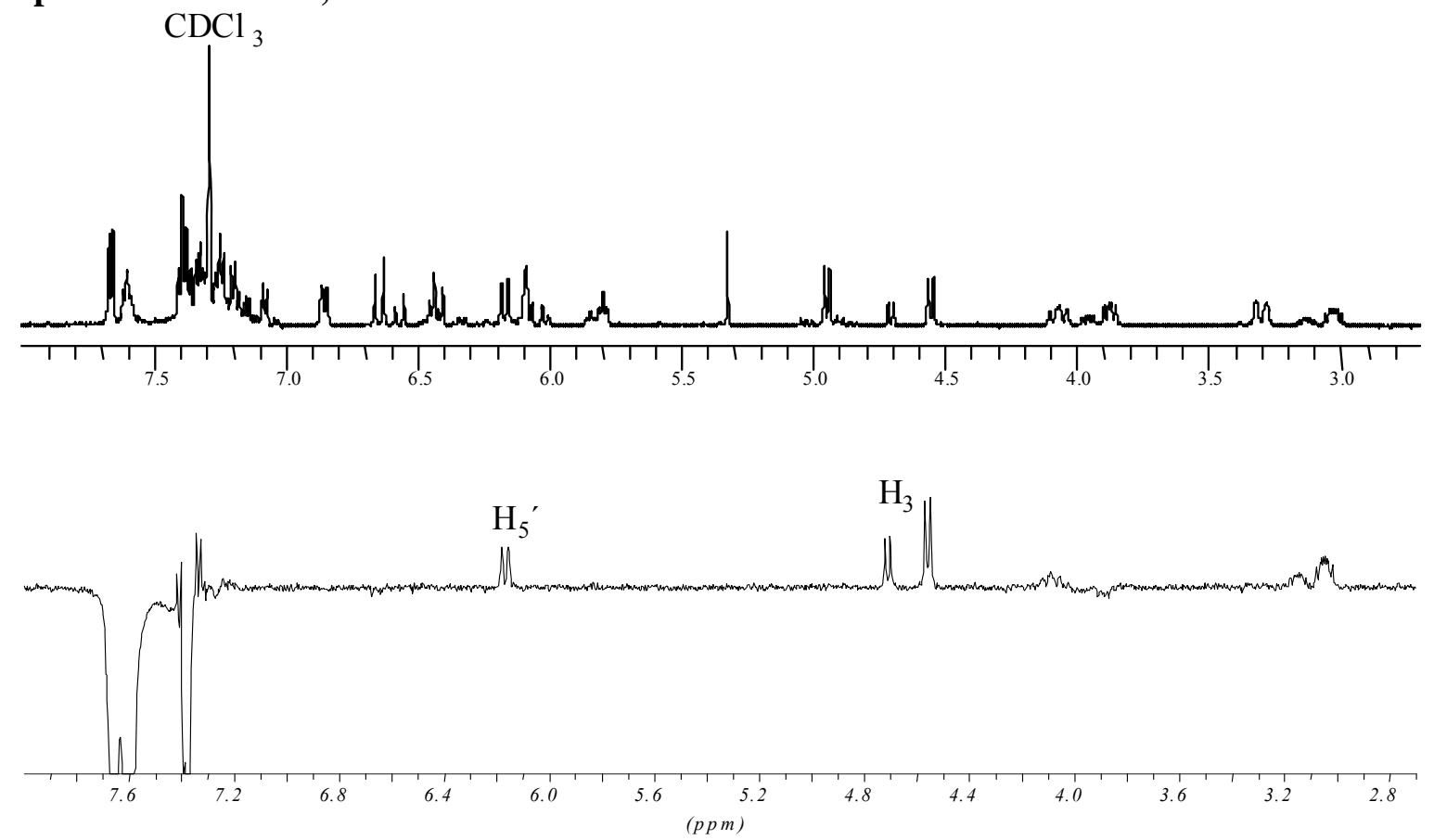
4) a) ${ }^{1} \mathrm{H} \mathrm{NMR}\left(500 \mathrm{MHz}, \mathrm{CDCl}_{3}\right)$ in the region of 2.7 to $9.3 \mathrm{ppm}$.

b-f) Difference Nuclear Overhauser Effect spectra of $E, Z-4$ with a lower left to upper right layout. The protons, which are irradiated, are depicted in parenthesis.
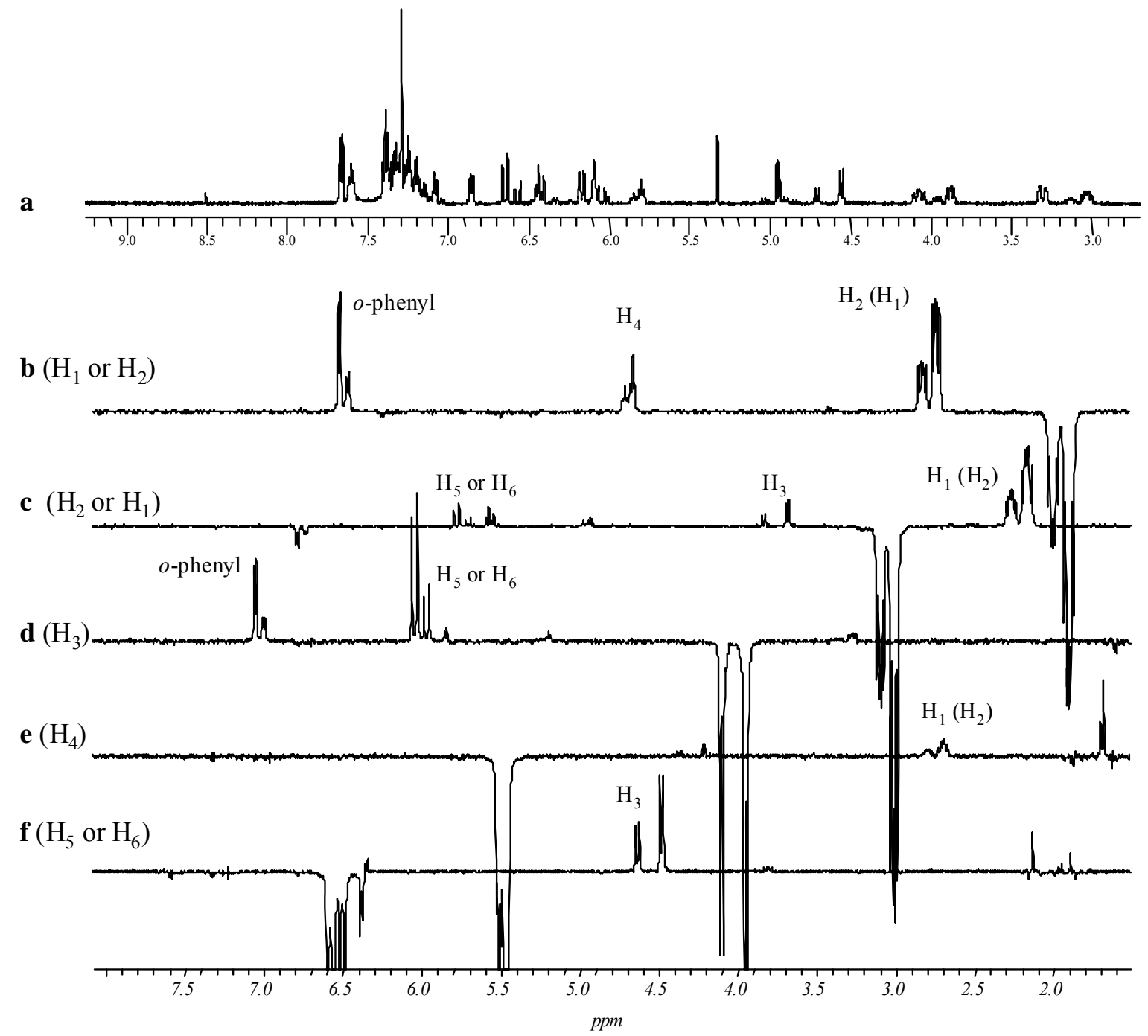
5) a) ${ }^{1} \mathrm{H}$ NMR (500 MHz, $\mathrm{CDCl}_{3}$ ) in the region of 2.70 to $9.25 \mathrm{ppm}$.

b-g) Difference Nuclear Overhauser Effect spectra of 3 with a lower left to upper right layout. The protons, which are irradiated, are depicted in parenthesis.

a
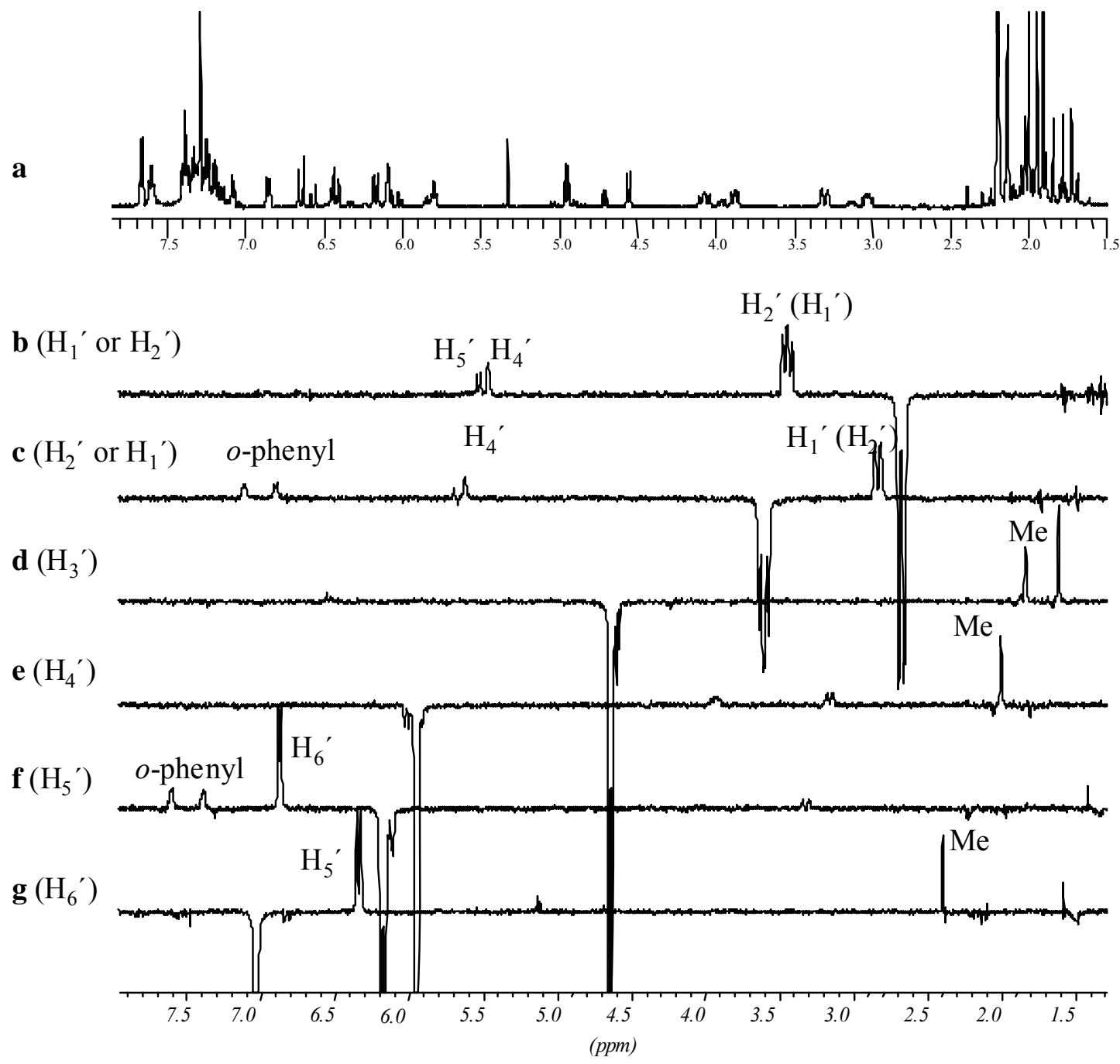
D) Diene $E$-cis-7, Z-cis-7, E-trans-7, and Z-trans-7

1) a) ${ }^{1} \mathrm{H}$ NMR (500 MHz, $\left.\mathrm{CDCl}_{3}\right)$

b) ${ }^{1} \mathrm{H}$ Homonuclear decoupling experiment. The following spectrum was recorded when the terminal vinylic methyl groups at 1.81 and $1.79 \mathrm{ppm}$ were irradiated. The four multiplets in the region between 5.30 to 5.70 collapsed to doublets with coupling constants $J_{\text {trans }}=15.0$ and $J_{\text {cis }}=9.5 \mathrm{~Hz}$.
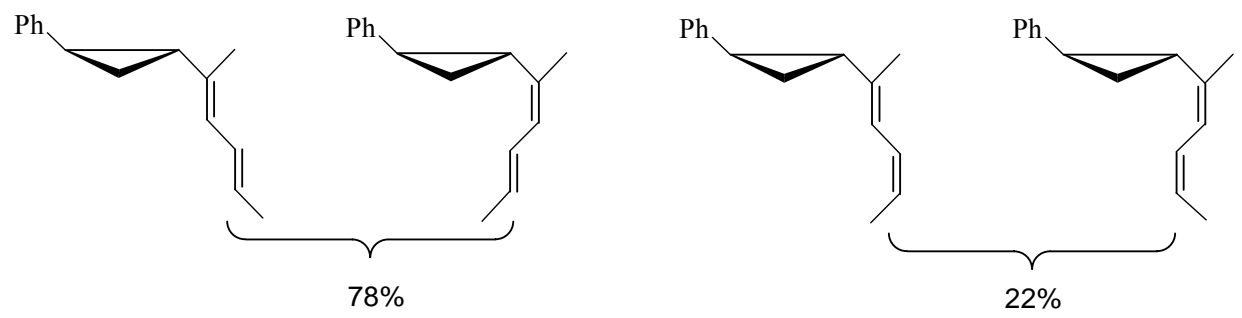

a)

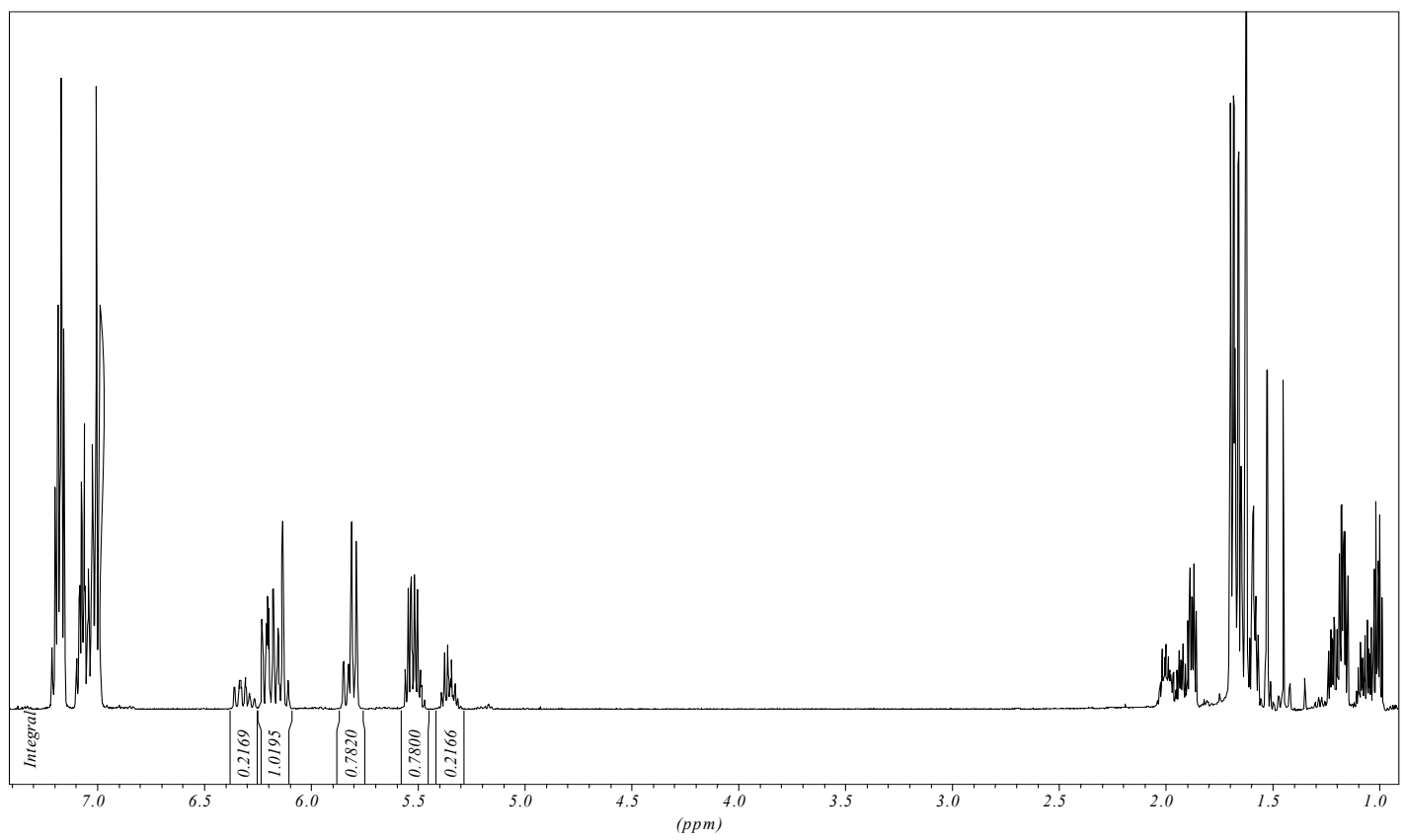

b)

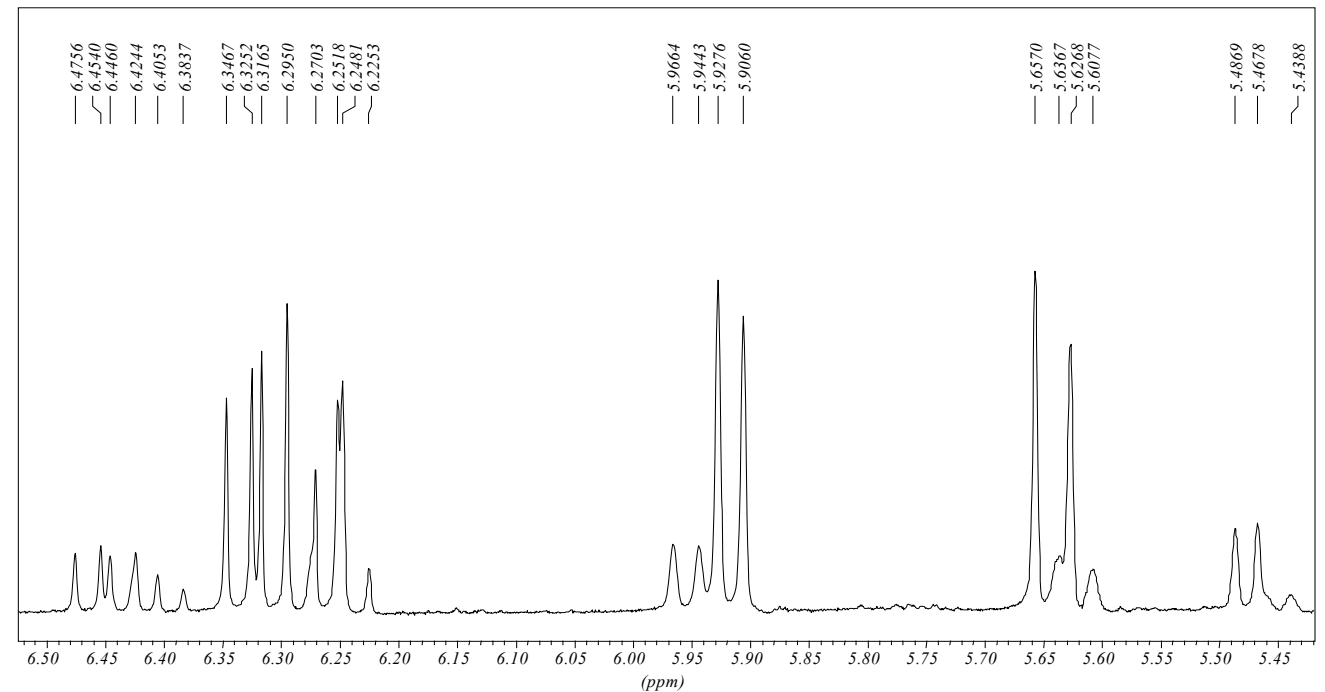


2) GC-MS of the mixture of $\boldsymbol{E}$-cis-7, Z-cis-7, E-trans-7, and Z-trans-7

*** CLASS-5000 *** Report No. = 1 Data : MX5.D01 00/12/13 17:35:48

Operator : mariax

Method File Name : MARIAX.MET
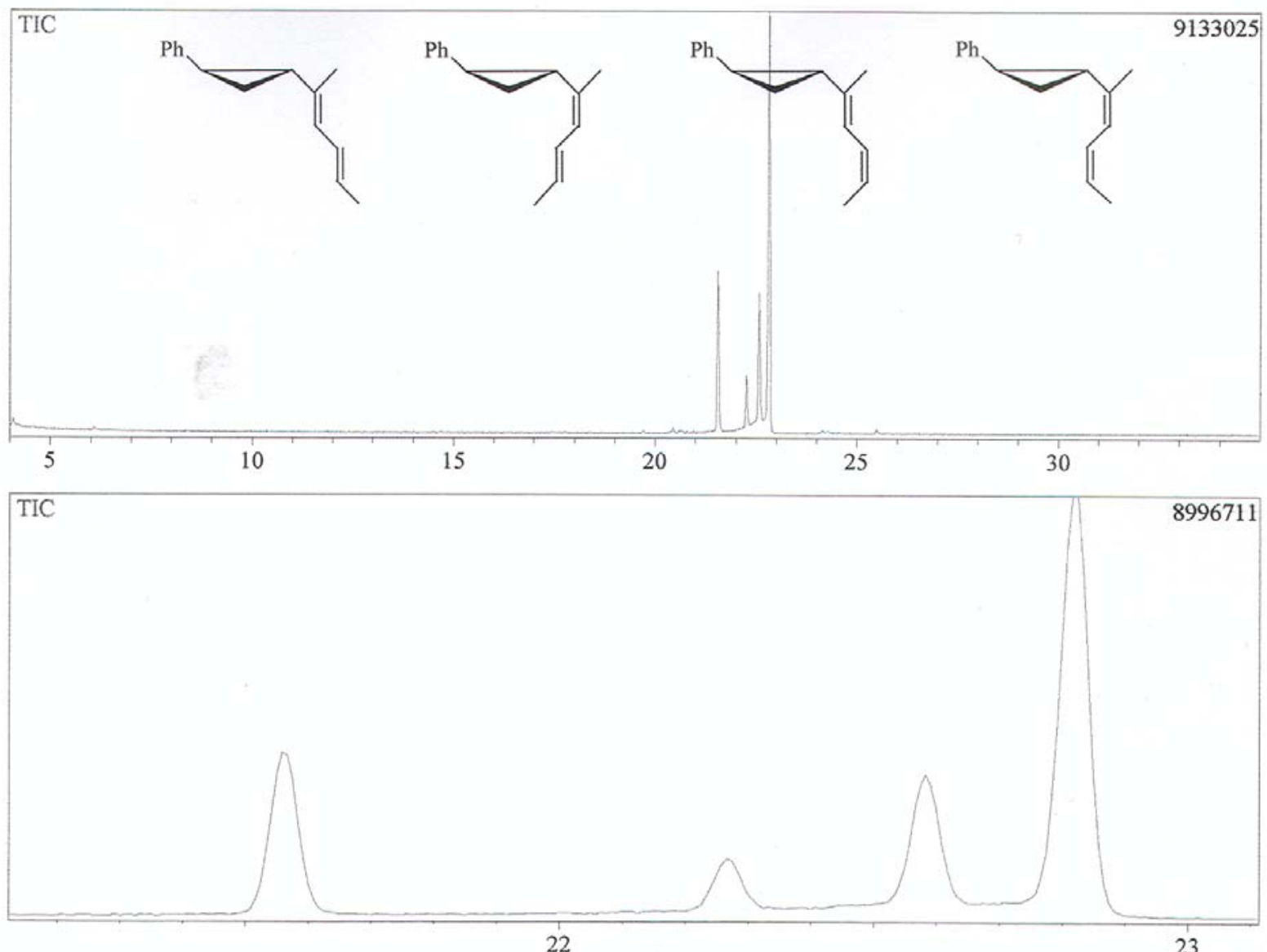

Scan \# : ( $2253-2266)$ B.G. Scan \# : 2277

Mass Peak \# : 150 Ret. Time : (22.767 - 22.875)

Base Peak :91.05 ( 481127)

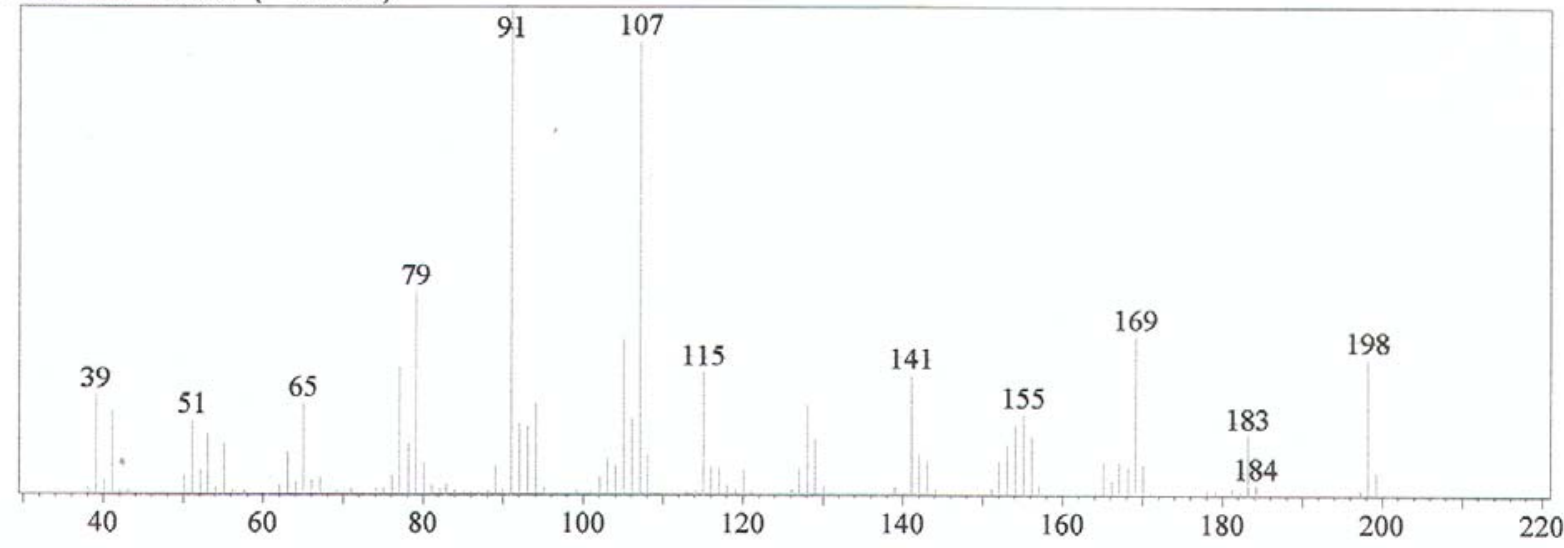


E) [60]Fullerene derivatives trans- and cis-E-syn-8

1) a) ${ }^{1} \mathrm{H}$ NMR (500 $\mathrm{MHz}, \mathrm{CDCl}_{3}$ ) in the region of 2.6 to $6.8 \mathrm{ppm}$.

b) Difference Nuclear Overhauser Effect spectrum of $E$-syn-8 which occurs when the $\mathrm{H}_{4}$ and $\mathbf{H}_{4}$ ' are irradiated. The enhancement of the doublets of the vinylic protons $\mathrm{H}_{5}$ and $\mathrm{H}_{5}$ ' depicts the $E$-stereochemistry of the trisubstituted double bond.

c) Integration of olefinic and cyclopentanic protons. The ratio trans/cis was measured to be 78/22.
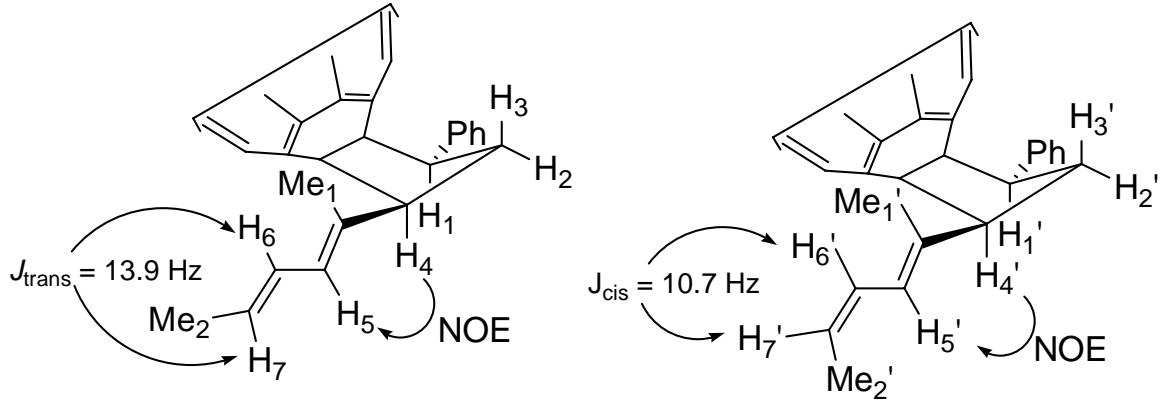

trans-E-syn-8

cis-E-syn-8

a)

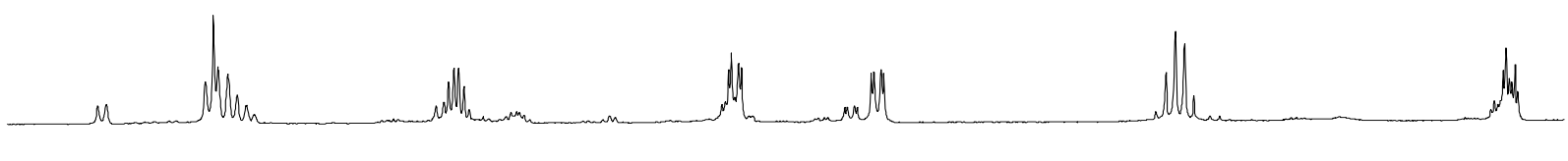

b)

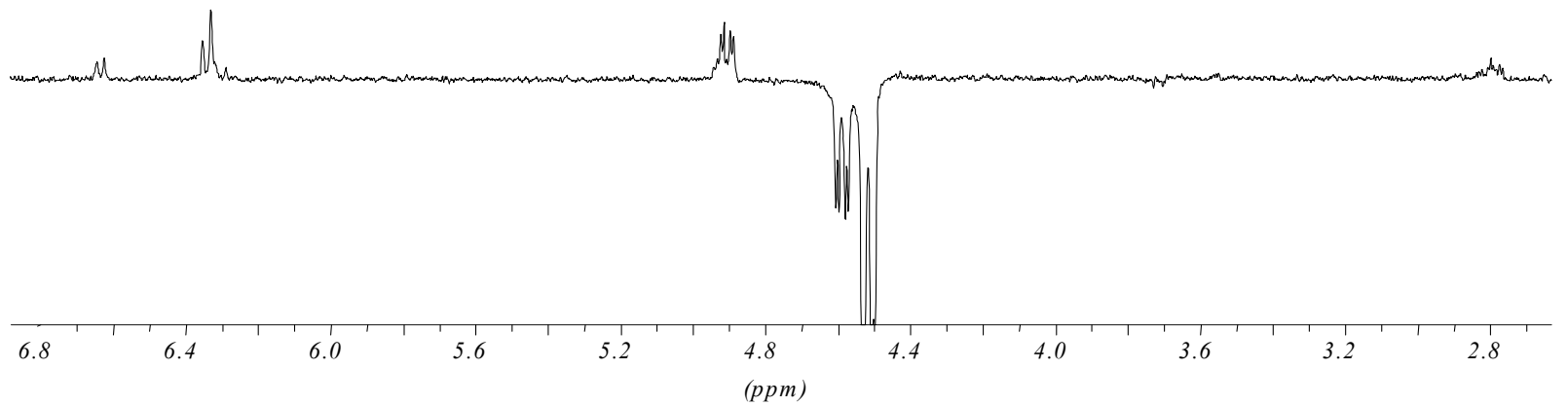

c)

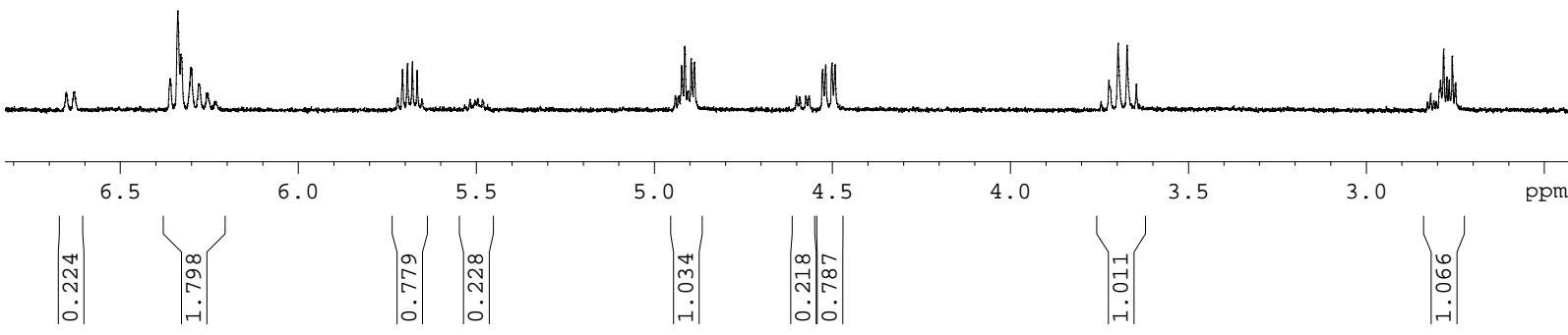

${ }^{\mathrm{i}}$ Paquette, L. A.; Ham W. H. J.Am.Chem.Soc. 1987, 109, 3025. 